\title{
Patterns of suspended particulate matter across the continental margin in the Canadian Beaufort Sea during summer
}

\author{
Jens K. Ehn ${ }^{1}$, Rick A. Reynolds ${ }^{2}$, Dariusz Stramski ${ }^{2}$, David Doxaran ${ }^{3}$, Bruno Lansard ${ }^{4}$, and Marcel Babin ${ }^{5}$ \\ ${ }^{1}$ Centre for Earth Observation Science, University of Manitoba, Winnipeg, Manitoba, Canada \\ ${ }^{2}$ Marine Physical Laboratory, Scripps Institution of Oceanography, University of California San Diego, \\ La Jolla, California, USA \\ ${ }^{3}$ Sorbonne Université, CNRS, Laboratoire d'Océanographie de Villefanche, Villefranche-sur-Mer, France \\ ${ }^{4}$ Laboratoire des Sciences du Climat et de l'Environnement, LSCE/IPSL, CEA-CNRS-UVSQ-Université Paris Saclay, \\ Gif-sur-Yvette, France \\ ${ }^{5}$ Joint International ULaval-CNRS Laboratory Takuvik, Québec-Océan, Département de Biologie, \\ Université Laval, Québec, Quebec, Canada
}

Correspondence: Jens K. Ehn (jens.ehn@umanitoba.ca)

Received: 2 June 2018 - Discussion started: 21 June 2018

Revised: 3 March 2019 - Accepted: 15 March 2019 - Published: 15 April 2019

\begin{abstract}
The particulate beam attenuation coefficient at $660 \mathrm{~nm}, c_{\mathrm{p}}(660)$, was measured in conjunction with properties of suspended particle assemblages in August 2009 within the Canadian Beaufort Sea continental margin, a region heavily influenced by freshwater and sediment discharge from the Mackenzie River, but also by sea ice melt. The mass concentration of suspended particulate matter (SPM) ranged from 0.04 to $140 \mathrm{~g} \mathrm{~m}^{-3}$, its composition varied from mineral to organic dominated, and the median particle diameter determined over the range $0.7-120 \mu \mathrm{m}$ varied from 0.78 to $9.45 \mu \mathrm{m}$, with the fraction of particles $<1 \mu \mathrm{m}$ in surface waters reflecting the degree influenced by river water. Despite this range in particle characteristics, a strong relationship between SPM and $c_{\mathrm{p}}(660)$ was found and used to determine SPM distributions across the shelf based on measurements of $c_{\mathrm{p}}(660)$ taken during summer seasons of 2004, 2008, and 2009. SPM spatial patterns on the stratified shelf reflected the vertically sheared two-layer estuarine circulation and SPM sources (i.e., fluvial inputs, bottom resuspension, and biological productivity). Along-shelf winds generated lateral Ekman flows, isopycnal movements, and upwelling or downwelling at the shelf break. Cross-shelf transects measured during three summers illustrate how sea ice meltwater affects river plume extent, while the presence of meltwater on the shelf was associated with enhanced near-bottom SPM during return flow of upwelled Pacific-origin water. SPM decreased
\end{abstract}

sharply past the shelf break with further transport of particulate matter occurring near the bottom and in interleaving nepheloid layers. These findings expand our knowledge of particle distributions in the Beaufort Sea controlled by river discharge, sea ice, and wind, each of which is sensitive to weather and climate variations.

\section{Introduction}

The Mackenzie Shelf in the southeastern Beaufort Sea (Arctic Ocean) is subject to great seasonal and interannual variability in its sea ice coverage (Galley et al., 2008; Yang, 2009; Stroeve et al., 2014), freshwater input (McClelland et al., 2012), and atmospheric forcing (Yang, 2009; Asplin et al., 2012; Moore, 2012; Kirillov et al., 2016), all of which strongly influence the water circulation and particle dynamics. The shelf is about $120 \mathrm{~km}$ wide, $500 \mathrm{~km}$ long, $<80 \mathrm{~m}$ deep, and is estimated to receive on average about $330 \mathrm{~km}^{3} \mathrm{yr}^{-1}$ of freshwater from the Mackenzie River with a sediment load of $130 \mathrm{Tg} \mathrm{yr}^{-1}$ (Macdonald et al., 1998; O'Brien et al., 2006). The large freshwater load, from both river runoff and sea ice melt, results in the Mackenzie Shelf displaying typical stratified estuarine circulation characteristics (Carmack and Macdonald, 2002). The Mackenzie Shelf is bordered to the east by Amundsen Gulf, to the west by the 
Mackenzie Trough, and is intersected at $\sim 134^{\circ} \mathrm{W}$ by Kugmallit Valley. These are all shown to be locations of intensified shelf-basin exchange driven by winds and modified by sea ice interactions (e.g., Dmitrenko et al., 2016; Forest et al., 2015; O'Brien et al., 2011; Williams and Carmack, 2008). Easterly along-shelf winds generate offshore Ekman transport of surface waters and upwelling of nutrient-rich Pacificorigin water onto the shelf, whereas westerly winds create downwelling flow and enhance offshore transport of sediment in the bottom boundary layer. Much of the sediment transport occurs during winter and is associated with storms, eddy transport, and sea ice brine convection (Forest et al., 2015; O’Brien et al., 2011).

The significance of sediment discharge to the region is underscored by the fact that this sediment load from the Mackenzie River surpasses the combined load of all other major rivers discharging into the Arctic Ocean. Additional sediment sources of minerogenic sediment to the shelf include coastal and bottom erosion and other rivers, which have been estimated to provide $\sim 9 \mathrm{Tg} \mathrm{yr}^{-1}$ (Macdonald et al., 1998). This makes the Mackenzie Shelf the most turbid shelf sea in the Arctic Ocean. Biological production, by both marine phytoplankton and sea-ice-associated algae towards the end of the ice-covered season, is a major autochthonous source of biogenous sediments in the Beaufort Sea during summer (Forest et al., 2007, 2010; Tremblay et al., 2008), although the ice and turbid seawater are thought to greatly limit primary production on the Mackenzie Shelf (Carmack and Macdonald, 2002). The particulate sinking flux therefore comprises highly variable fractions of allochthonous and autochthonous origins (Sallon et al., 2011), making particle characterization in the area a complex task. The vertical export of autochthonous organic material to the deep waters of the Canada Basin is found to be surprisingly small, however (Honjo et al., 2010). As the organic material reaching the deep ocean layers is thousands of years old it must be transported there laterally from the shelf or slope reservoirs of highly refractory material (Honjo et al., 2010). This highlights the importance of understanding the distribution and lateral transport of particulate material from the shelf.

The mechanisms and pathways of cross-shelf and slope particle transport in the Beaufort Sea continental margin remain poorly understood (O'Brien et al., 2011). This is largely because of a lack of data of sufficient resolution; biogeochemically important constituents in such a large and dynamic system are difficult to characterize with traditional methods that rely on discrete water sampling. To infer particle transport pathways, a description of the distribution and variability of particle concentrations associated with the factors controlling the water circulation is required. Ocean color remote sensing of suspended particles provides a much better spatial coverage but is limited to surface waters during cloudfree conditions during certain periods of the seasonal cycle. In situ optical techniques, most commonly involving a measurement of beam attenuation coefficient, allow a significant increase in observational time and space scales. The beam attenuation at a light wavelength of $660 \mathrm{~nm}$ has been typically used in these relationships. Because beam attenuation is sensitive not only to the concentration of particles but also their size and composition, numerous relationships have been developed to relate the particulate beam attenuation coefficient, $c_{\mathrm{p}}(\lambda)$ (where $\lambda$ is light wavelength in vacuo) to the dry mass concentration of suspended particulate matter (SPM) and particulate organic carbon (POC) (e.g., Bishop, 1986, 1999; Bunt et al., 1999; Gardner et al., 2006; Stramski et al., 2008; Jackson et al., 2010; Hill et al., 2011). The relationships are affected by the proportion of organic to inorganic material because mineral particles typically have a higher refractive index compared to organic particles and thus generally produce higher scattering per unit mass concentration (e.g., Babin et al., 2003b; Woźniak et al., 2010). Beam attenuation is also affected by variable absorption. In particular, at $660 \mathrm{~nm}$ the absorption by chlorophyll pigments may cause important distinctions between organic and inorganic material (Doxaran et al., 2012; Bélanger et al., 2013). Particle size is of importance because the scattering cross section of individual particles typically increases as particle size increases (Morel and Bricaud, 1986; Stramski and Kiefer, 1991). However, particle concentration often decreases significantly with an increase in particle size so that relatively small particles can have a higher contribution to bulk scattering per unit mass concentration of particles than larger particles (Babin et al., 2003b; Reynolds et al., 2010; Hill et al., 2011).

Because of various origins and variable composition of particle assemblages in the southeastern Beaufort Sea, the feasibility of inferring SPM and POC from beam attenuation has been questioned for this region (Jackson et al., 2010). Nevertheless, in this study we use a comprehensive set of field data collected as part of the MALINA project in summer 2009 in waters with diverse composition of particulate matter characterized by variation in the ratio of POC/SPM to determine statistical relationships between the particulate beam attenuation coefficient at $660 \mathrm{~nm}, c_{\mathrm{p}}(660)$, and SPM and POC. These relationships are then applied to infer the particle concentration fields from the measurements of $c_{\mathrm{p}}(660)$. The distribution of SPM and POC on the Mackenzie Shelf displayed complex spatial variability that could not be explained in terms of a single parameter. The variability was found to be related to forcing and oceanographic conditions (wind speed and direction, sea ice coverage, and freshwater content and source), both present and foregone, which control the circulation and water mass properties on the shelf. To gain a better contextual understanding of the effect of the forcing and oceanographic conditions on particle concentration fields, we compare and contrast the MALINA observations to two other expeditions in the southeastern Beaufort Sea during the open-water season that also included beam attenuation measurements. 


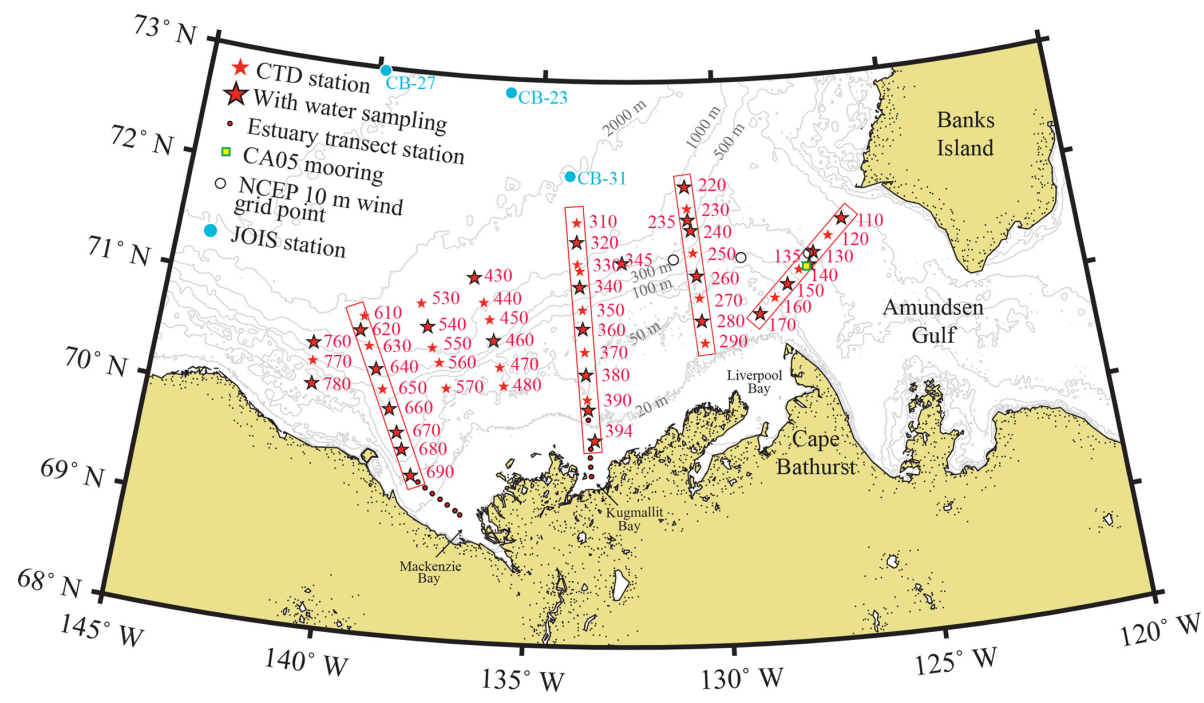

Figure 1. Map of study area with stations sampled along transect lines 100 to 700 during the MALINA expedition in 2009. Stars indicate stations visited by CCGS Amundsen, and small circles indicate the estuarine stations sampled by the barge. CTD rosette water sampling was conducted at the 28 stations marked by stars with black borders. Black circles are the three locations selected for NCEP $10 \mathrm{~m}$ winds. The green-yellow square near station 140 indicates the location of the long-term mooring CA05 with a current meter at $178 \mathrm{~m}$. The cyan circles mark the locations for three of the profiles shown in Fig. 9. The fourth station, CB-21, was located $1^{\circ}$ north of CB-27.

\section{Materials and methods}

\subsection{MALINA sampling overview}

The MALINA expedition was conducted from 31 July to 24 August 2009 in the southeastern Beaufort Sea on the research icebreaker CCGS Amundsen. A total of 167 CTD rosette casts were carried out during the expedition with water sampling conducted at 28 station locations (Fig. 1). The locations, sampling times, and bottom depths are provided in Table S1 in the Supplement. A small barge was launched to conduct coincident surface water sampling away from the ship's influence on 26 of these stations. In addition, the barge visited 12 additional stations in coastal waters too shallow for the ship (Fig. 1; Doxaran et al., 2012). The CTD rosette on board the icebreaker was equipped with $2412 \mathrm{~L}$ Niskin bottles for water collection and various in situ instruments including an SBE 911plus CTD (Sea-Bird Electronics, Inc.), a C-Star $25 \mathrm{~cm}$ beam transmissometer (WET Labs, Inc.) for measuring the particulate beam attenuation coefficient at $660 \mathrm{~nm}, c_{\mathrm{p}}(660)$, and a WETstar fluorometer (WET Labs, Inc.) for measuring fluorescence of chlorophyll $a(\operatorname{chl} a)$.

\subsection{Determinations of SPM and POC}

Niskin bottles were triggered during CTD rosette upcasts to collect water samples at three to four depths, which always included the near-surface water (1.5-3 m depth range) and subsurface chlorophyll- $a$ maximum (SCM) if present. To ensure representative sampling of entire particle assemblages within Niskin bottles (including particles settled be- low the level of the spigot), the full content of the $12 \mathrm{~L}$ Niskin bottles was drained directly into 20 L HDPE carboys (Nalgene) by opening the bottom lid (Knap et al., 1996). Aliquots were then sampled from the carboys after mixing. If a sufficient volume of water was available, filtration for SPM and POC determinations was made in triplicate for each examined depth. However, this was not always possible in clear waters with low particle concentrations, in which case either duplicates or single samples were prepared. Water samples for SPM and POC on the barge were collected by directly submerging a $20 \mathrm{~L}$ HDPE carboy below the sea surface (Doxaran et al., 2012). Doxaran et al. (2012) reports on coefficients of variation for SPM and POC for these surface samples measured in triplicate. Additional near-surface water samples were occasionally collected by lowering a bucket from the side of the ship.

Water samples for SPM and POC were filtered through $25 \mathrm{~mm}$ diameter Whatman GF/F filters under low vacuum $(\leq 5 \mathrm{psi})$. Prior to the cruise the filters for both SPM and POC determinations had been rinsed with Milli-Q water, combusted at $450^{\circ} \mathrm{C}$ for $1.5 \mathrm{~h}$ to remove organic material, and weighed using a Mettler Toledo MT5 balance $( \pm 0.001 \mathrm{mg}$ precision) to obtain the blank measurement of the filter mass. Filters were stored individually in petri dishes until the time of sample filtration. The volume of filtered seawater was adjusted to optimize particle load on the filter but not to cause filters to clog. This volume ranged from $0.2 \mathrm{~L}$ for very turbid samples collected near the Mackenzie River mouth (station 697 ) to $5.8 \mathrm{~L}$ at station 780 . Immediately following filtration, filters were rinsed with about $50 \mathrm{~mL}$ of Milli-Q water to remove salts, transferred back to the petri slides, and dried 
for $6-12 \mathrm{~h}$ at $55^{\circ} \mathrm{C}$. The dried filters were stored at $-80^{\circ} \mathrm{C}$ until processing. After the cruise, filters were again dried at $55^{\circ} \mathrm{C}$ in the laboratory for about $24 \mathrm{~h}$ before measuring their dry weight using the same Mettler Toledo MT5 balance. The SPM (in units of grams per cubic meter) was determined by subtracting the blank filter mass from the sample filter mass and dividing by the volume of water filtered. The relative humidity of the room was about or below $40 \%$ during weighing of filters to minimize the effect of uptake of moisture by the filters during the measurements. The protocol used for SPM determinations is consistent with standard methodology (e.g., Babin et al., 2003a).

SPM and POC were determined on the same GF/F filters. After the weighing for SPM, POC content was determined with an organic elemental analyzer (PerkinElmer 2400 Series II CHNS/O) with a standard high-temperature combustion method as described in Doxaran et al. (2012). Prior to insertion of samples into the analyzer, the filters were acidified with $200-350 \mu \mathrm{L}$ of $2 \mathrm{~N} \mathrm{HCl}$ to remove inorganic carbon and then dried at $60^{\circ} \mathrm{C}$. Filters were compacted into small ( $\sim 5 \mathrm{~mm}$ diameter) rounded pellets within pre-combusted aluminum foil. Blank filters for POC determinations were treated and measured in the same way as sample filters. The combustion temperature was kept at $925^{\circ} \mathrm{C}$. The final POC values (in units of grams per cubic meter) were calculated by dividing the mass of organic carbon measured (in units of micrograms) on the sample filter (corrected for blank filter) by the filtered volume. In these calculations, the correction for blank filters was made using the average mass concentration of organic carbon determined on nine blank filters, which was determined to be $21.2 \pm 8.1 \mu \mathrm{g}$ (corresponding to a range of $\sim 2$ to $50 \%$ of measured signal for the sample filters).

\subsection{Particle size distributions}

The particle size distribution (PSD) of 54 discrete seawater samples collected with the CTD rosette or from the barge were measured using a Beckman Coulter Multisizer III analyzer following the method described by Reynolds et al. (2016). In 40 of these samples, data were collected using both the 30 and $200 \mu \mathrm{m}$ aperture sizes and merged into a single PSD ranging from 0.7 to $120 \mu \mathrm{m}$. Seawater filtered through a $0.2 \mu \mathrm{m}$ filter was used as the diluent and blank, and multiple replicate measurements were acquired for each sample. Each aperture was calibrated using microsphere standards following recommendations by the manufacturer. The average number of particles per unit volume within each size class, $N(D)$ (per cubic meter), where $D$ is the midpoint diameter of the volume-equivalent sphere in each size class, was obtained after subtracting the counts for the blank. The particle volume distribution, $V(D)$ (dimensionless), was then calculated from $N(D)$ by assuming spherical particles.

\subsection{Beam attenuation measurements}

C-Star transmissometer data were recorded at $24 \mathrm{~Hz}$ as raw voltages and merged with the depth recording from the CTD rosette. Downcasts were processed to $1 \mathrm{~m}$ vertical bins centered at integers by averaging the interquartile range of the voltages within bins. This method effectively removed spikes and noise from the data, if present. Time series of transmissometer data were also collected at selected depths and processed similarly to above, by taking the average of the interquartile range of the voltage values recorded over the periods when the rosette was stopped for water sampling during upcasts. These data were used for correlational analysis with SPM and POC data from discrete Niskin bottle water samples. The particulate beam attenuation coefficient at $660 \mathrm{~nm}$, $c_{\mathrm{p}}(660)$ (in reciprocal meters), was then calculated from the binned voltage signal, $V_{\text {signal }}$, as

$c_{\mathrm{p}}(660)=-\ln \left(\frac{V_{\text {signal }}-V_{\text {dark }}}{V_{\text {ref }}-V_{\text {dark }}}\right) / x$,

where $x$ is the pathlength of $0.25 \mathrm{~m}, V_{\text {dark }}$ is the dark voltage offset, and $V_{\text {ref }}$ is the reference voltage associated with particle-free pure seawater (see C-Star User's Guide, WET Labs, Inc.). For MALINA, $V_{\text {ref }}$ was taken as the highest $V_{\text {signal }}$ reading observed during the expedition, i.e., it was determined to be $4.7362 \mathrm{~V}$ (lower than the factory-supplied value of $4.8340 \mathrm{~V}$ ) observed with the same instrument during the Geotraces cruise that immediately followed the MALINA cruise (cast 0903_26 on 4 September at depths between 1900 and $2500 \mathrm{~m}$ where water temperature and salinity averaged $-0.40{ }^{\circ} \mathrm{C}$ and $34.94 \mathrm{PSU}$, respectively). This $V_{\text {ref }}$ was only marginally higher than maximum values observed during the MALINA expedition. The above method also assumes a negligible contribution by CDOM to $c_{\mathrm{p}}$ at $660 \mathrm{~nm}$ (Bricaud et al., 1981), which is a reasonable assumption based on data shown in Matsuoka et al. (2012). $V_{\text {dark }}$ was found to be $0.0517 \mathrm{~V}$ when measured immediately after a deep cast when the temperature of the instrument was equilibrated to seawater temperature. The factory supplied value was $0.061 \mathrm{~V}$. However, discrepancies in $V_{\text {dark }}$ are of little significance compared to $V_{\text {ref }}$. For example, for relatively turbid conditions with $V_{\text {signal }}$ as low as $3.7 \mathrm{~V}$ (representing a $c_{\mathrm{p}}(660)$ of $\left.1 \mathrm{~m}^{-1}\right)$, the change from 0.0517 to 0.061 reduces the calculated $c_{\mathrm{p}}(660)$ by only $0.2 \%$.

In this study we also use the C-Star transmissometer data obtained during CASES (2004) and IPY-CFL (2008) expeditions on the CCGS Amundsen (Ingram et al., 2008; Barber et al., 2010) to compare and contrast to the MALINA observations. The data were processed in the same way as the MALINA 2009 downcast data. One exception was that the factory-supplied $V_{\text {dark }}$ values were used exclusively as they had not been determined on board the vessels. The $V_{\text {dark }}$ values were 0.0570 and $0.0586 \mathrm{~V}$ for the CASES and IPY-CFL expeditions, respectively. The highest $V_{\text {signal }}$ readings were 4.6783 and $4.7902 \mathrm{~V}$, respectively. 
Four deep CTD casts were additionally collected in the Canada Basin during the Joint Ocean Ice Study (JOIS) on 21-23 September 2009 and the data were obtained from the Beaufort Gyre Exploration Program website hosted by the Woods Hole Oceanographic Institution. These transmissometer data were processed as described above with a $V_{\text {dark }}$ value of $0.0633 \mathrm{~V}$ (factory calibration) and $V_{\text {ref }}$ value of $4.9408 \mathrm{~V}$ (maximum recorded value at station $\mathrm{CB}-21$ on 9 October 2009).

\subsection{Determination of surface water mass distributions}

During the MALINA expedition, water samples were collected at 51 stations on the Mackenzie Shelf by either the CTD rosette or from the barge. Oxygen isotope ratios $\left(\delta^{18} \mathrm{O}\right)$ were analyzed at the Light Stable Isotope Geochemistry Laboratory (GEOTOP-Université du Québec à Montréal) using a triple collector IRMS in dual-inlet mode with a precision of $\pm 0.05 \%$ o. Total alkalinity (TA) was measured by opencell potentiometric titration (TitraLab $865^{\circledR}$ radiometer) with a combined pH electrode (pHC2001, Red $\left.\operatorname{Rod}^{\circledR}\right)$ and diluted $\mathrm{HCl}(0.03 \mathrm{M})$ as a titrant. Oxygen isotopes and TA collected during CASES 2004 are described, and partially published, in Lansard et al. (2012). We use salinity $(S), \delta^{18} \mathrm{O}$, and TA data to estimate the fractional composition of sea ice meltwater $\left(f_{\mathrm{SIM}}\right)$ and meteoric water $\left(f_{\mathrm{MW}}\right)$ in the surface layer on the Mackenzie Shelf, following the protocol described in Lansard et al. (2012). The calculations follow Yamamoto-Kawai et al. (2008) and Lansard et al. (2012) with the sea ice melt (SIM) end members 4.7 PSU, $-2.5 \%$, and $415 \mu \mathrm{mol} \mathrm{kg}{ }^{-1}$; the meteoric water (MW) end members 0 PSU, $-19.5 \%$, and $1620 \mu \mathrm{mol} \mathrm{kg}{ }^{-1}$; and the saline Pacific Summer Water $\left(f_{\mathrm{PSW}}\right)$ end members $31.5 \mathrm{PSU},-3.0 \%$, and $2250 \mu \mathrm{mol} \mathrm{kg}^{-1}$ for $S, \delta^{18} \mathrm{O}$, and TA, respectively. The Mackenzie River represents the major source of meteoric water on the Mackenzie Shelf.

\subsection{Additional environmental data}

To describe ocean currents, temperature, and salinity near the shelf break, in addition to CTD casts we used data from a current meter (RCM11, Aanderaa Data Instruments) moored at station CA05 near the center of line 100 (Fig. 1). The locations where the mooring CA05 was deployed and the depth of the current meter varied slightly between years. During season 2003-2004, it was deployed in $250 \mathrm{~m}$ deep water $\left(71.42^{\circ} \mathrm{N}, 127.37^{\circ} \mathrm{W}\right)$ at a depth of $202 \mathrm{~m}$. In 2007-2008 and 2008-2009, the bottom depth was about $200 \mathrm{~m}\left(71.31^{\circ} \mathrm{N}\right.$, $127.60^{\circ} \mathrm{W}$ ) and the instrument depth $178 \mathrm{~m}$. In addition to current speed and direction, the instrument recorded water temperature, conductivity, turbidity, and dissolved oxygen content, all at $0.5 \mathrm{~h}$ intervals. The conductivity sensor did not function in 2007-2008.

Annual estimates of Mackenzie River discharge and ice concentrations on the Canadian Beaufort Sea shelf for the years 2004, 2008, and 2009 were obtained from publicly available data provided by Environment Canada. Daily discharge rates (in units of cubic meters per second) for the Mackenzie River at the Arctic Red River location (10LC014) were obtained from Water Survey of Canada (Environment Canada) hydrometric data online archives. Ice coverage with a 1-week resolution for the Mackenzie Shelf area was calculated using the IceGraph 2.0 program (region: cwa01_02) provided online by the Canadian Ice Service (Environment Canada).

Estimates of wind speed over the shelf were obtained by averaging $10 \mathrm{~m}$ elevation wind data over grid points located over the shelf break in the southeastern Beaufort Sea obtained from National Centers for Environmental Prediction (NCEP) (Fig. 1). As pointed out by Williams et al. (2006), NCEP data are readily available and may be preferable over observations made at coastal stations because the latter may be affected by the presence of land. We use the NCEP wind data in a qualitative sense to identify conditions that may have induced upwelling or downwelling of seawater within the shelf area (e.g., Kirillov et al., 2016).

\section{Results and discussion}

\subsection{Water mass distributions and circulation during August 2009}

During the MALINA cruise in August 2009, there was a distinct east-west gradient in the observed surface salinity on the shelf (Fig. 2a). To the west, surface salinities below 24 PSU were caused by the presence of the river plume that flowed along the coast and over the Mackenzie Trough in response to easterly winds during June 2009 (see Sect. 3.3.3). The river plume formed a near-surface layer of about 15$20 \mathrm{~m}$ in thickness, which covered the full extent of line 600 and line 700 . To the east, water with salinity above 29 PSU was observed to reach the surface in the area north of Cape Bathurst. Williams and Carmack (2008) described such upwelling from within the Amundsen Gulf as topographically induced in response to easterly winds. Salinity values in excess of 32 PSU were measured near the shelf bottom at $30 \mathrm{~m}$ (Fig. 2c), which corresponds to Pacific waters in Amundsen Gulf at a depth of about $80 \mathrm{~m}$ (Fig. 2e). Generally, for the Arctic Ocean, salinity controls the vertical stratification such that higher salinity is found at greater depth. The water mass definition that ensues follows Carmack et al. (1989) and is consistent with descriptions in Lansard et al. (2012) and Matsuoka et al. (2012). The salinity range between 30.7 and 32.3 PSU corresponds to the Pacific Summer Water mass, which originates from waters flowing through Bering Strait during summer. Underneath, the Pacific Winter Water is characterized by salinity between 32.3 and 33.9 PSU and typically found at a depth from $\sim 180$ to $220 \mathrm{~m}$ (e.g., Jackson et al., 2015). This is followed by a transition to wa- 

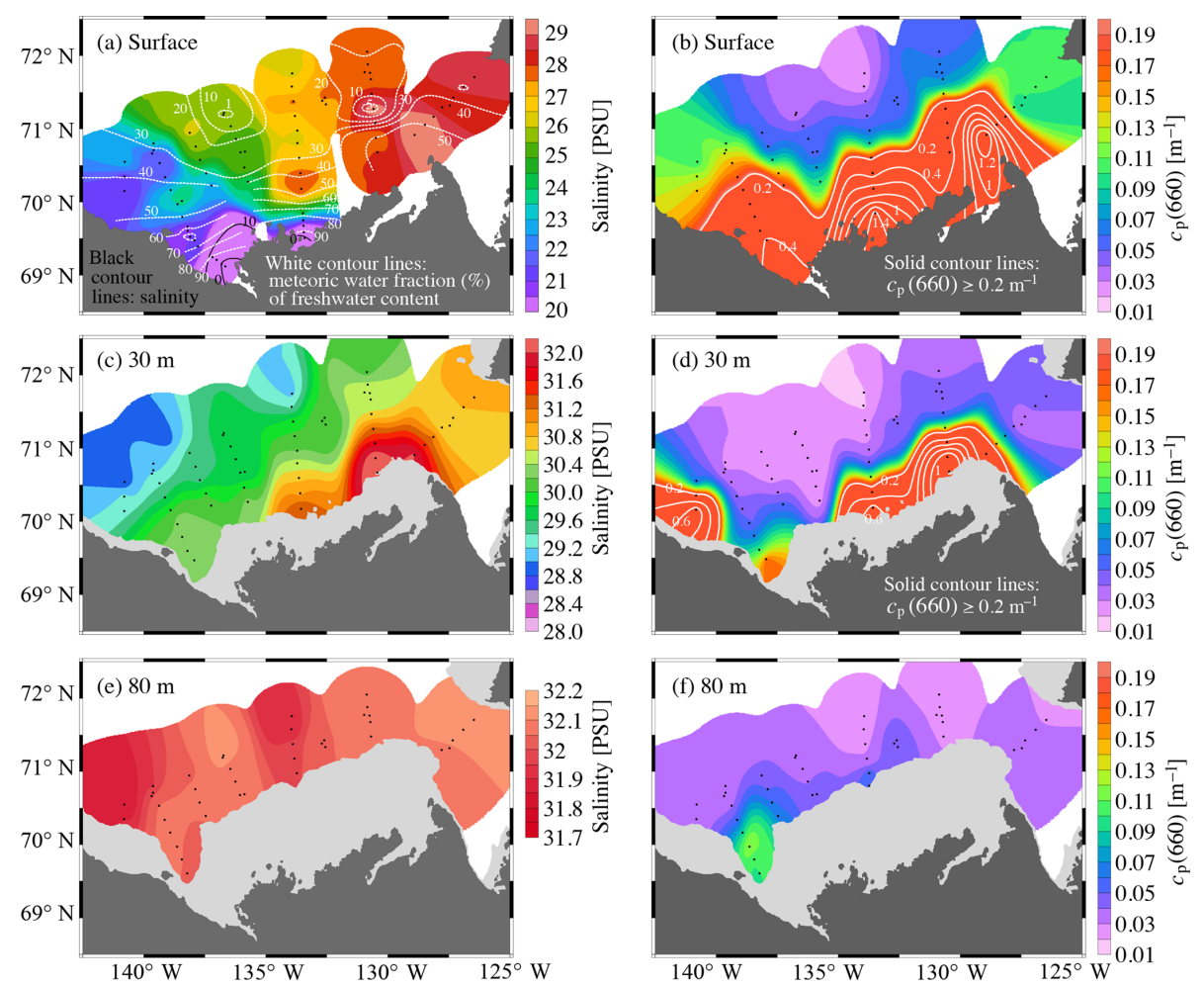

Figure 2. Fields of water salinity (a, c, e) and particulate beam attenuation coefficient at $660 \mathrm{~nm}(\mathrm{cp}(660)$, a, c, e) for (a)-(b) sea surface, (c)-(d) $30 \mathrm{~m}$, and (e)-(f) $80 \mathrm{~m}$ during the MALINA 2009 expedition. The presented results in (a) include both barge and only CTD rosette measurements from the CCGS Amundsen, but only CTD rosette measurements in (b)-(f) marked by black dots. Black contour lines in (a) mark salinity in the estuary, while the white dashed contour lines are the fraction of meteoric water (\%) of the freshwater calculated using samples collected by both barge and CTD rosette.

ters of Atlantic origin with salinity $>34.7$ and temperature above $0{ }^{\circ} \mathrm{C}$ typically found between $\sim 220$ and $800 \mathrm{~m}$. Cold and dense deep water is found at greater depths and down to the bottom.

The relative contributions (\%) of the two sources to the freshwater content, i.e., meteoric water $f_{\mathrm{MW}}$ and sea ice meltwater $f_{\mathrm{SIM}}$, in the surface layer are shown by the contours in Fig. 2a. The percent values are calculated as follows: $f_{\mathrm{MW}} /\left(f_{\mathrm{MW}}+f_{\mathrm{SIM}}\right) \times 100$. Apart from the Mackenzie River mouth, the freshwater in the surface layer was a mixture between sea ice melt and river runoff. River water prevailed along the coastline, while sea ice melt had a larger contribution further offshore. A larger river water fraction also extended further along the west coast with the northwestflowing river plume. In the upwelling region north of Cape Bathurst, river runoff and ice melt contributed about equal amounts to the relatively small freshwater content of $\sim 10 \%$. The high ice melt proportions in excess of $80 \%$ were found in offshore waters with melting multi-year sea ice (Bélanger et al., 2013).

Geostrophic currents for the cross-shelf sections 100, 200, 300 , and 600 were calculated using temperature and salinity data from August 2009 CTD casts (Fig. 3). The reference depth, where the current velocity was assumed to be zero, was selected as $500 \mathrm{~m}$, corresponding to a water mass originating in the Atlantic in which geopotential gradients are small (McPhee, 2013). The sections reveal a westward mean flow of up to $9 \mathrm{~cm} \mathrm{~s}^{-1}$ in the Canada Basin (Fig. 3b, c), which is consistent with the anticyclonic circulation of the Beaufort Gyre. Similarly, currents over the shelf were typically westward with speeds on the order of a few centimeters per second. A notable feature was the presence of the eastward-flowing shelf break current centered between 100 and $150 \mathrm{~m}$ depth (Pickart, 2004). The shelf break current is an indicator for downwelling flow from the shelf to the basin (Dmitrenko et al., 2016). Both Dmitrenko et al. (2016) and Forest et al. (2015) present mooring data collected at the Mackenzie Shelf shelf break location showing events of wind-driven shelf break current intensifications (with flow up to $1.2 \mathrm{~m} \mathrm{~s}^{-1}$ in January 2005) during downwelling favorable winds. However, to our knowledge, the current intensification along the Mackenzie Shelf shelf break during summer has not been shown in the literature to date. The mean easterly flow was around $3 \mathrm{~cm} \mathrm{~s}^{-1}$ (Fig. 3a-c), which is consistent with the observations of Pickart (2004) for the summertime period along the Alaskan Beaufort shelf break. The section along line 600 in the Mackenzie Trough captured an anticyclonic mesoscale eddy ( $\sim 50 \mathrm{~km}$ diameter), which im- 

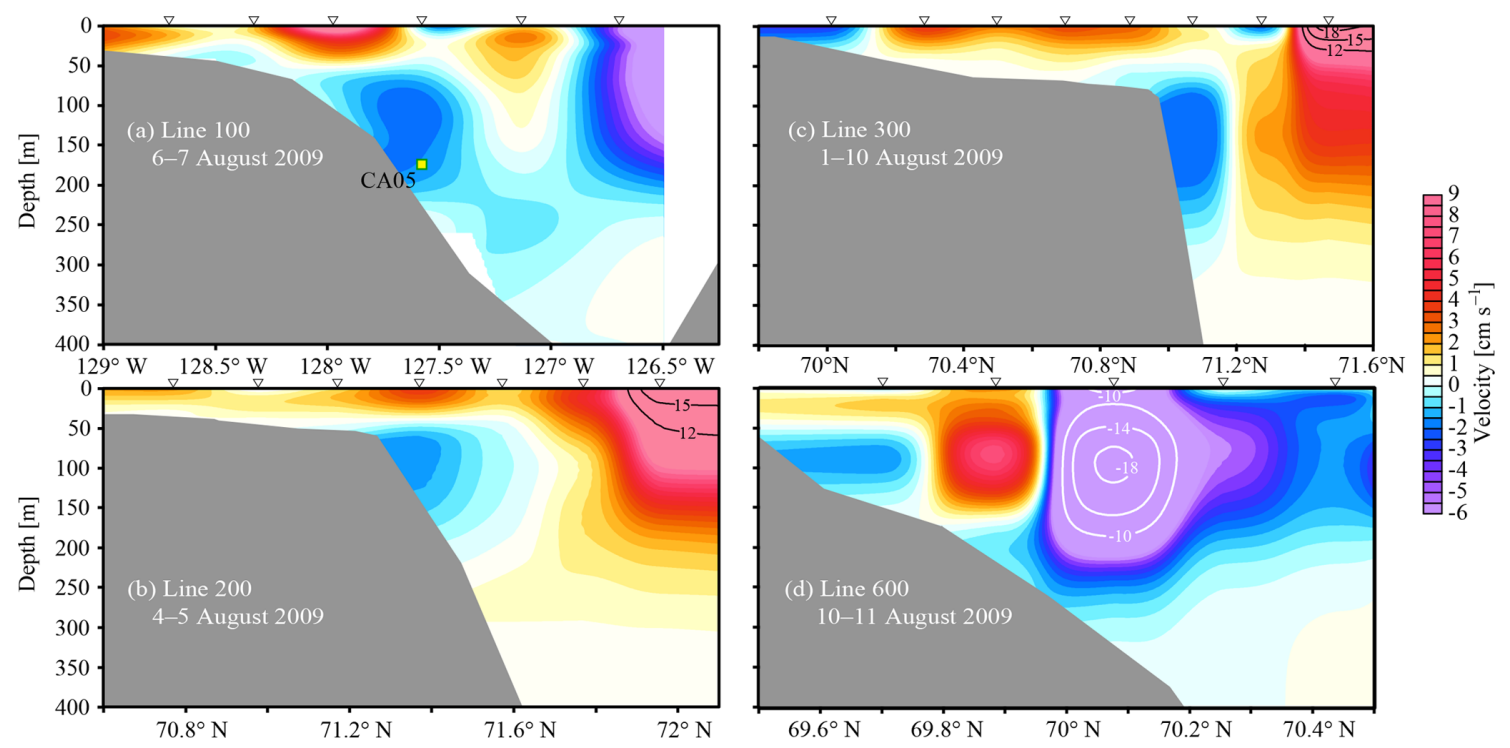

Figure 3. Sections of geostrophic current velocity (colors and white contours) perpendicular to transect lines 100 (a), 200 (b), 300 (c), and 600 (d). Geopotential heights were referenced to $500 \mathrm{~m}$. Positive current values are generally for the direction perpendicular to the transect lines (see Fig. 1) towards the northwest (a), west (b-c), or southwest (d). The green-yellow square in (a) indicates the location of the current meter on the CA05 mooring.

pacted the patterns of $c_{\mathrm{p}}(660)$ and chl- $a$ fluorescence (see below).

\subsection{Characteristics of particles suspended in seawater in August 2009}

Empirical relationships between the beam attenuation coefficient and SPM are dependent on the composition and size distribution of particle assemblages (Kitchen et al., 1982; Bunt et al., 1999; Babin et al., 2003b; Reynolds et al., 2010; Woźniak et al., 2010; Hill et al., 2011). In this section we present several water characteristics encountered in August 2009 that help understand the origin of suspended particles and composition of particle assemblages in the Canadian Beaufort Sea. The absorption associated with organic and inorganic material is described elsewhere (Doxaran et al., 2012; Bélanger et al., 2013). However, the measured particulate absorption at $660 \mathrm{~nm}$ was found to be smaller by $1-4$ orders of magnitude than $c_{\mathrm{p}}(660)$ and can thus be ignored (data not shown). Particle size distributions during MALINA and the relationship to backscattering are described in Reynolds et al. (2016). The environmental conditions encountered during MALINA showed large spatial variability; yet, a statistically significant and strong correlation was found between the particulate beam attenuation coefficient $\left(c_{\mathrm{p}}(660)\right)$ and SPM, as well as POC (see Sect. 3.3). Although we recognize the possibility of interannual and seasonal variability in particle characteristics, the wide range of particle characteristics observed during the MALINA expedition gives us confidence in the applicability of the derived statistical relation- ships to infer suspended particle concentration fields on the Mackenzie Shelf and southeastern Beaufort Sea.

Generally, $c_{\mathrm{p}}(660)$ in the near-surface layer decreased from $>1 \mathrm{~m}^{-1}$ in coastal waters to $<0.02 \mathrm{~m}^{-1}$ in offshore Canada Basin waters (Fig. 2), reflecting the riverine and coastal sources of particulate matter. To the west, the fresher surface layer influenced by the river plume featured relatively high $c_{\mathrm{p}}(660)$ ranging from 0.1 to $0.4 \mathrm{~m}^{-1}$ (Fig. 2b) and high colored dissolved organic matter (CDOM) fluorescence (Fig. 4; Matsuoka et al., 2012). The highest ship-based observation of surface-water $c_{\mathrm{p}}(660)$ of $\sim 2.6 \mathrm{~m}^{-1}$ was observed at station 394 in $13 \mathrm{~m}$ deep waters at the mouth of Kugmallit Bay; however, $c_{\mathrm{p}}(660)$ reached $8.8 \mathrm{~m}^{-1}$ at a depth of $10 \mathrm{~m}$ and presumably higher values near the seabed. The surface waters in the area of upwelling just north of Cape Bathurst appear to also have been a hot spot in terms of particle concentration; $c_{\mathrm{p}}(660)$ at the surface of station 170 reached values over $1.2 \mathrm{~m}^{-1}$ (Fig. $2 \mathrm{~b}$ ).

The high $c_{\mathrm{p}}(660)$ values near the shelf seafloor in August 2009 were accompanied by a strong chl- $a$ fluorescence signal, both of which also extended from the shelf far into the Canada Basin as a subsurface chl- $a$ maximum (SCM) layer (Fig. 4a, c, e). The SCM layer is a consistent feature in the southern Beaufort Sea during summer (Martin et al., 2010). The SCM was centered at depths between the 31.5 and 32.3 PSU isohalines, which corresponds to the lower portion of the Pacific Summer Water. The underlying Pacific Winter Water is characterized by maxima in both nutrients and CDOM (Fig. 4; Matsuoka et al., 2012). The nutrient maximum is typically found at the center of the Pacific Winter Water near the 33.1 PSU isohaline (Martin et al., 2010). 

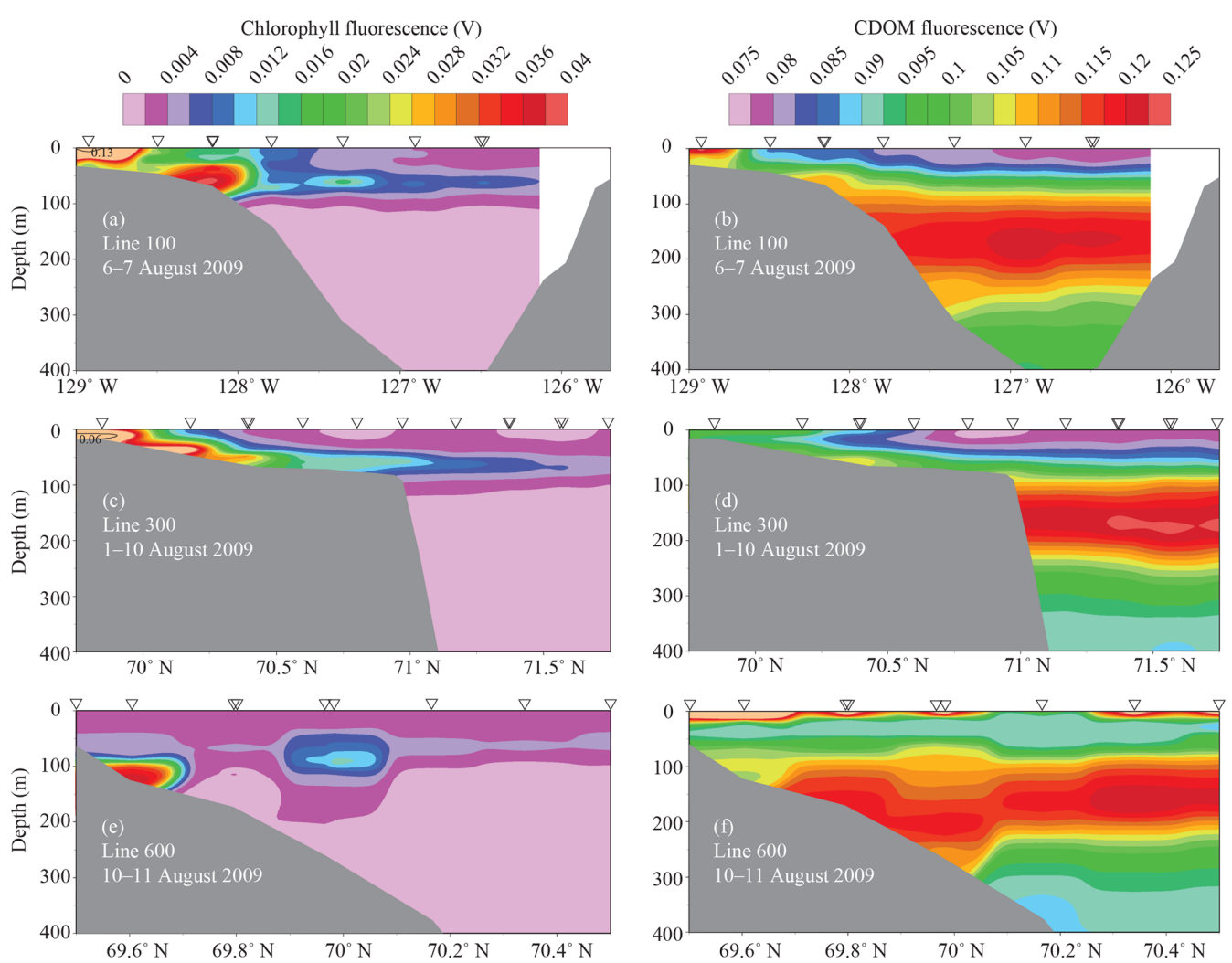

Figure 4. Voltage readings from the chlorophyll fluorometer (a, c, e) and CDOM fluorometer (b, d, f) for transects (a-b) 100, (c-d) 300, and (e-f) 600 .

Following Woźniak et al. (2010), the data representing discrete seawater samples were partitioned into three composition-related groups based on the POC/SPM ratio: (1) mineral dominated when POC/SPM $<6 \%$, (2) mixed when $6 \% \leq \mathrm{POC} / \mathrm{SPM} \leq 25 \%$, and (3) organic dominated when POC/SPM $>25 \%$. Only at station $394(13 \mathrm{~m}$ bottom depth) near the entrance to Kugmallit Bay did the CTD rosette sampling from the CCGS Amundsen take place sufficiently close to the coast to reach the mineral-dominated water masses (Fig. 5a). However, the results from barge sampling in August 2009 show that mineral-dominated particle composition was mostly limited to shallow waters less than about $20 \mathrm{~m}$ deep near the two Mackenzie River mouths where $f_{\mathrm{MW}}$ contributed $>90 \%$ of the freshwater content (Fig. 5a). This agrees with past observations suggesting that most mineral-dominated particles transported by the Mackenzie River plume settle to the bottom within the delta or shortly after reaching the shelf where the plume speed decreases (Macdonald et al., 1998). For the rest of the shelf and basin surface waters the particle composition in our collected samples showed considerable variability within the organic-dominated and mixed types (Fig. 5). The one exception was, however, the surface sample at station 110 located furthest east in the Amundsen Gulf where the POC/SPM was less than $1.8 \%\left(\mathrm{SPM}=3.56 \mathrm{~g} \mathrm{~m}^{-3}\right)$. Although the possibil- ity of contamination of the sample from station 110 cannot be excluded, the high SPM load could also have been caused by the release of ice-rafted sediments as the ice melted (Bélanger et al., 2013). Deteriorated multi-year ice was observed in the vicinity of station 110 , which could have been the source of minerogenic material. Sea ice meltwater was found to have a slightly larger contribution at station 110 compared to other stations along line 100 (Table 1).

For a detailed description of the particle size distribution (PSD) data measured during MALINA, readers are referred to Reynolds et al. (2016). Here, we provide an overview of the spatial distribution of the PSD by calculating the volume fraction of particles less than $1 \mu \mathrm{m}$ in diameter $D$ to the total particle volume between 0.7 and $120 \mu \mathrm{m}$. A notable feature in the particle volume distribution, $V(D)$, was the presence of high concentrations of $<1 \mu \mathrm{m}$ volume fractions in surface waters and their reduced abundance in subsurface waters (Fig. 5c). The highest increase in the abundance of submicron particles relative to larger particles was found in samples collected furthest to the west along lines 600 and 700 where surface water salinity associated with the river plume was less than 24 PSU. A similar observation also pertains to the surface water sample from station 380 located near the Mackenzie River's Kugmallit Bay channel, even though the salinity was $\sim 28$ PSU (Fig. 5c). However, the fraction of meteoric 
Table 1. Salinity, saline end member, meteoric and sea ice melt fractions (\%), and meteoric water percentage of freshwater content $(\mathrm{MW} \%=$ $\left.f_{\mathrm{MW}} /\left(f_{\mathrm{MW}}+f_{\mathrm{SIM}}\right) \times 100\right)$ for surface seawater samples obtained at matching station locations during CASES 2004 and MALINA 2009. A few matching stations were also sampled during IPY-CFL 2008. The samples were collected with Niskin bottles on a CTD rosette. The fraction of the saline end member $\left(f_{\mathrm{PSW}}\right)$ represents Pacific Summer Water with a salinity of 31.5 PSU.

\begin{tabular}{|c|c|c|c|c|c|c|}
\hline Cruise & Station & Salinity & $f_{\mathrm{PSW}}$ & $f_{\mathrm{MW}}$ & $f_{\mathrm{SIM}}$ & MW\% \\
\hline CASES & 110 & 25.4 & 80.1 & 6.6 & 13.3 & 34.8 \\
\hline \multirow[t]{11}{*}{2004} & 140 & 27.8 & 84.6 & 5.1 & 10.4 & 33.2 \\
\hline & 150 & 29.3 & 89.1 & 7.5 & 3.4 & 68.6 \\
\hline & 170 & 29.8 & 91.0 & 7.0 & 2.1 & 77.5 \\
\hline & 320 & 29.4 & 89.2 & 1.3 & 9.4 & 12.2 \\
\hline & 340 & 27.1 & 81.4 & 3.4 & 15.2 & 18.3 \\
\hline & 360 & 25.1 & 79.9 & 19.6 & 0.5 & 97.5 \\
\hline & 380 & 24.8 & 76.2 & 19.5 & 4.3 & 82.0 \\
\hline & 390 & 25.4 & 78.8 & 20.4 & 0.8 & 96.3 \\
\hline & 660 & 15.9 & 48.5 & 40.9 & 7.7 & 79.3 \\
\hline & 670 & 16.9 & 52.6 & 40.2 & 7.2 & 84.7 \\
\hline & 690 & 8.8 & 26.0 & 60.5 & 13.5 & 81.8 \\
\hline IPY-CFL & 110 & 28.2 & 85.1 & 4.9 & 10.1 & 32.5 \\
\hline \multirow[t]{5}{*}{2008} & 140 & 28.2 & 85.1 & 4.3 & 10.6 & 28.8 \\
\hline & 160 & 30.3 & 91.6 & 3.7 & 4.7 & 44.4 \\
\hline & $320^{*}$ & 26.3 & 79.5 & 12.4 & 8.1 & 60.5 \\
\hline & $340^{*}$ & 25.0 & 75.5 & 17.5 & 7.1 & 71.1 \\
\hline & 390 & 29.4 & 88.9 & 11.0 & 0.2 & 98.6 \\
\hline MALINA & 110 & 28.9 & 86.6 & 4.8 & 8.6 & 35.6 \\
\hline \multirow[t]{10}{*}{2009} & 150 & 29.4 & 89.4 & 4.9 & 5.7 & 46.1 \\
\hline & 170 & 29.3 & 89.9 & 6.3 & 3.9 & 62.0 \\
\hline & 320 & 26.5 & 79.2 & 6.3 & 14.5 & 30.2 \\
\hline & 340 & 26.9 & 79.7 & 4.5 & 15.6 & 22.2 \\
\hline & 360 & 26.5 & 78.4 & 4.6 & 17.0 & 21.2 \\
\hline & 380 & 27.7 & 83.1 & 6.1 & 10.8 & 36.0 \\
\hline & 390 & 27.2 & 83.5 & 7.8 & 8.7 & 47.2 \\
\hline & 660 & 21.9 & 63.9 & 17.0 & 19.1 & 47.1 \\
\hline & 670 & 23.4 & 68.0 & 15.3 & 16.7 & 47.8 \\
\hline & 690 & 27.2 & 67.2 & 18.6 & 14.2 & 56.7 \\
\hline
\end{tabular}

* Approximately $5 \mathrm{nmi}$ south of station, which is halfway to the next station.

water was similar to that at station 620 (Fig. 5d). The PSD measurements for low salinity, highly turbid samples nearest to the river mouth (stations 390,394 , and 690) were not possible due to limitations of the Coulter technique. Station 110 stands out among line 100 stations with $<1 \mu \mathrm{m}$ volume fractions of 0.29 at the surface (salinity of 29.1 PSU) and 0.09 at $60 \mathrm{~m}$ (31.6 PSU).

To conclude, from the data in Fig. 5 we find that (1) when $f_{\mathrm{MW}}$ increased in the surface waters of the southeast Beaufort Sea, POC/SPM ratios decreased while the $<1 \mu \mathrm{m}$ particle fraction increased, and conversely (2) when the $f_{\mathrm{SIM}}$ influence increased, POC/SPM increased while the $<1 \mu \mathrm{m}$ particle fraction decreased in surface waters.

\subsection{Relationships between SPM, POC, and particulate beam attenuation}

The SPM of the samples examined during the MALINA cruise ranged from 0.04 to $140 \mathrm{~g} \mathrm{~m}^{-3}$ with associated POC from 0.007 to $1.5 \mathrm{~g} \mathrm{~m}^{-3}$ (Doxaran et al., 2012). Organicdominated and mixed particle assemblages were predominant in the portion of the dataset obtained from ship-based sampling, with SPM extending to $5.6 \mathrm{~g} \mathrm{~m}^{-3}$. The mineralrich particle assemblages were more common in turbid estuarine waters located close to shore (Fig. 5a). These waters were sampled using a small barge with an optical package that included a WET Labs AC-9 meter (Doxaran et al., 2012) but no WET Labs C-Star $660 \mathrm{~nm}$. The nearest wavelength band on the AC-9 was $676 \mathrm{~nm}$. It thus provided $c_{\mathrm{p}}(676)$. Note that much higher sediment loads were observed in the region in the past. For example, Carmack and Macdonald 

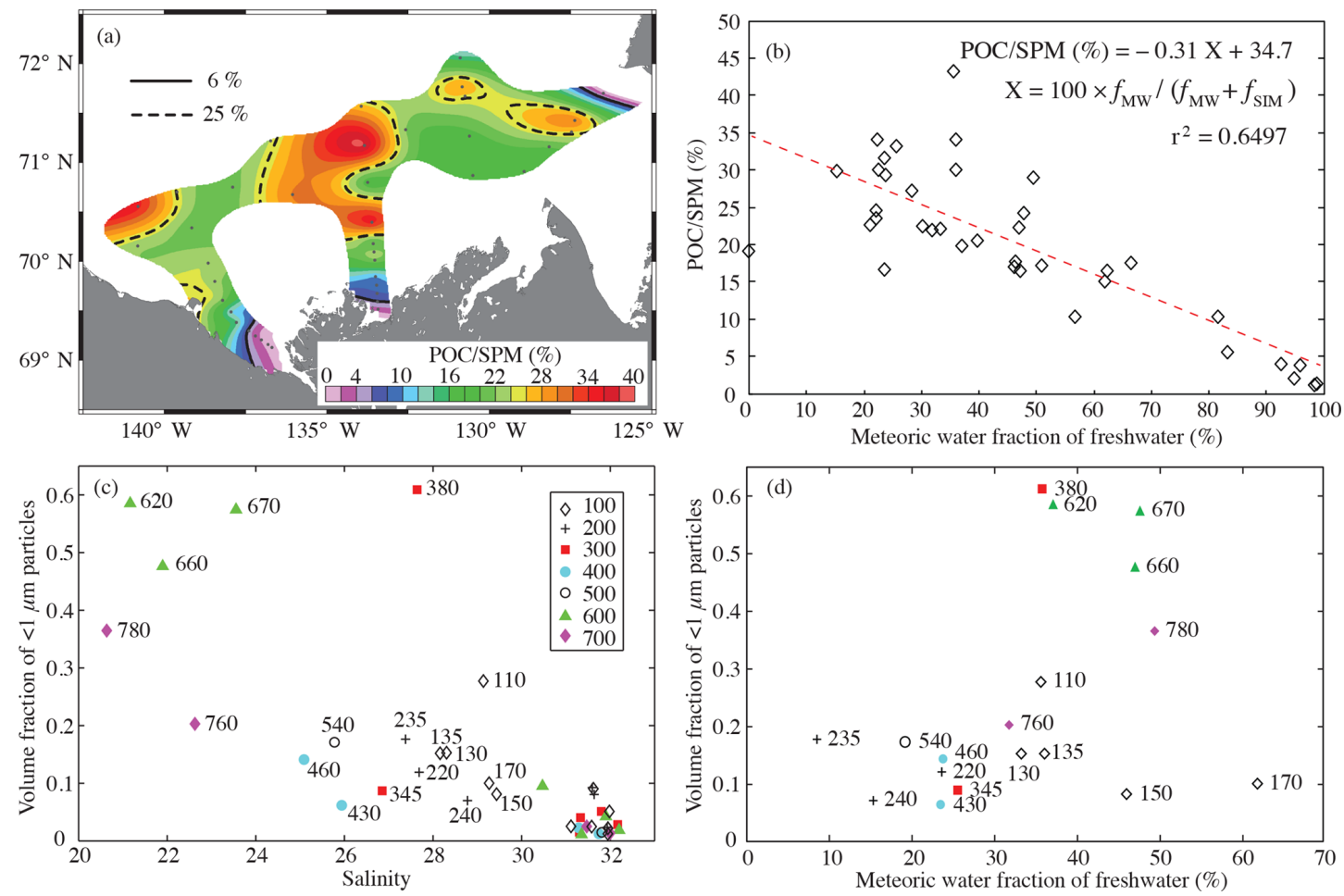

Figure 5. (a) POC-to-SPM ratio for surface samples within the study area, (b) relationship between POC-to-SPM ratio and meteoric water fraction of freshwater in surface waters (see Fig. 2a), and relationship between volume fraction of particles less than $1 \mu \mathrm{m}$ in diameter and (c) salinity, and (d) meteoric water fraction of freshwater. Values in (a), (b), and (d) are limited to surface water samples, while data points in (c) with salinities over 30 PSU represent subsurface samples.

(2002, their Fig. 10) reported near-bottom SPM values of $3000 \mathrm{~g} \mathrm{~m}^{-3}$ due to resuspension of bottom sediments during a storm in September 1987.

Data from all 28 stations with coincident measurements were used in the development of relationships between $c_{\mathrm{p}}(660)$ and SPM and between $c_{\mathrm{p}}(660)$ and POC. The particulate beam attenuation coefficient correlated well with both SPM and POC (Fig. 6a, b).

$\mathrm{SPM}=1.933 c_{\mathrm{p}}(660)^{0.9364}$

and

$\mathrm{POC}=0.2071 c_{\mathrm{p}}(660)^{0.6842}$,

where SPM and POC are in grams per cubic meter and $c_{\mathrm{p}}(660)$ in per meter, with $r^{2}$ of 0.71 and 0.74 , respectively. Further details on the evaluation of the regression fits are provided in the Supplement. In some instances, for example in biogeochemical modeling studies, the objective may be to estimate light transmission from SPM or POC that has been either measured or is available as model output. For this case the best-fit regression functions are $c_{\mathrm{p}}(660)=0.4267 \mathrm{PM}^{0.9068}$ and $c_{\mathrm{p}}(660)=3.088 \mathrm{POC}^{1.098}$, respectively.

The slopes of the best-fit lines (with intercepts set to zero) obtained through linear fitting to all pairs of $c_{\mathrm{p}}(660)$ vs. SPM and $c_{\mathrm{p}}(660)$ vs. POC data were $0.404 \mathrm{~m}^{2} \mathrm{~g}^{-1}\left(r^{2}=0.70\right)$ and $3.39 \mathrm{~m}^{2} \mathrm{~g}^{-1}\left(r^{2}=0.72\right)$, respectively. These slope values represent average SPM-specific and POC-specific particulate beam attenuation coefficients, respectively, for the examined dataset. Our average SPM-specific particulate beam attenuation coefficient at $660 \mathrm{~nm}$ is consistent with the range $0.2-0.6 \mathrm{~m}^{2} \mathrm{~g}^{-1}$ reported by Boss et al. (2009) and Hill et al. (2011) for a $12 \mathrm{~m}$ deep coastal site in the North Atlantic Ocean (Martha's Vineyard, MA, USA). Our average POC-specific value is near the middle of the range from $2.31 \mathrm{~m}^{2} \mathrm{~g}^{-1}$ at $c_{\mathrm{p}}(660)=0.45 \mathrm{~m}^{-1}$ to $4.10 \mathrm{~m}^{2} \mathrm{~g}^{-1}$ at $c_{\mathrm{p}}(660)=0.07 \mathrm{~m}^{-1}$ observed by Stramska and Stramski (2005) in the north polar Atlantic. Jackson et al. (2010) reported beam attenuation vs. SPM and POC correlations for measurements in the Arctic Ocean in 2006-2007, from which we estimate SPM-specific values of $0.34-0.50 \mathrm{~m}^{2} \mathrm{~g}^{-1}$ and POC-specific values of $3.4-3.7 \mathrm{~m}^{2} \mathrm{~g}^{-1}$ for the $c_{\mathrm{p}}(660)$ range from 0.07 to $0.45 \mathrm{~m}^{-1}$. The slopes calculated from our data within this same $c_{\mathrm{p}}(660)$ range were $0.46 \mathrm{~m}^{2} \mathrm{~g}^{-1}$ $\left(r^{2}=0.57\right)$ for $c_{\mathrm{p}}(660)$ vs. SPM and $2.47 \mathrm{~m}^{2} \mathrm{~g}^{-1}\left(r^{2}=0.69\right)$ for $c_{\mathrm{p}}(660)$ vs. POC, with the latter being consistent with other datasets (e.g., Cetinić et al., 2012) but notably smaller than the Jackson et al. (2010) value.

The data of SPM used in fitting the relationship of SPM vs. $c_{\mathrm{p}}(660)$ range from about 0.04 to $5.6 \mathrm{~g} \mathrm{~m}^{-3}$ (Fig. 6a). 

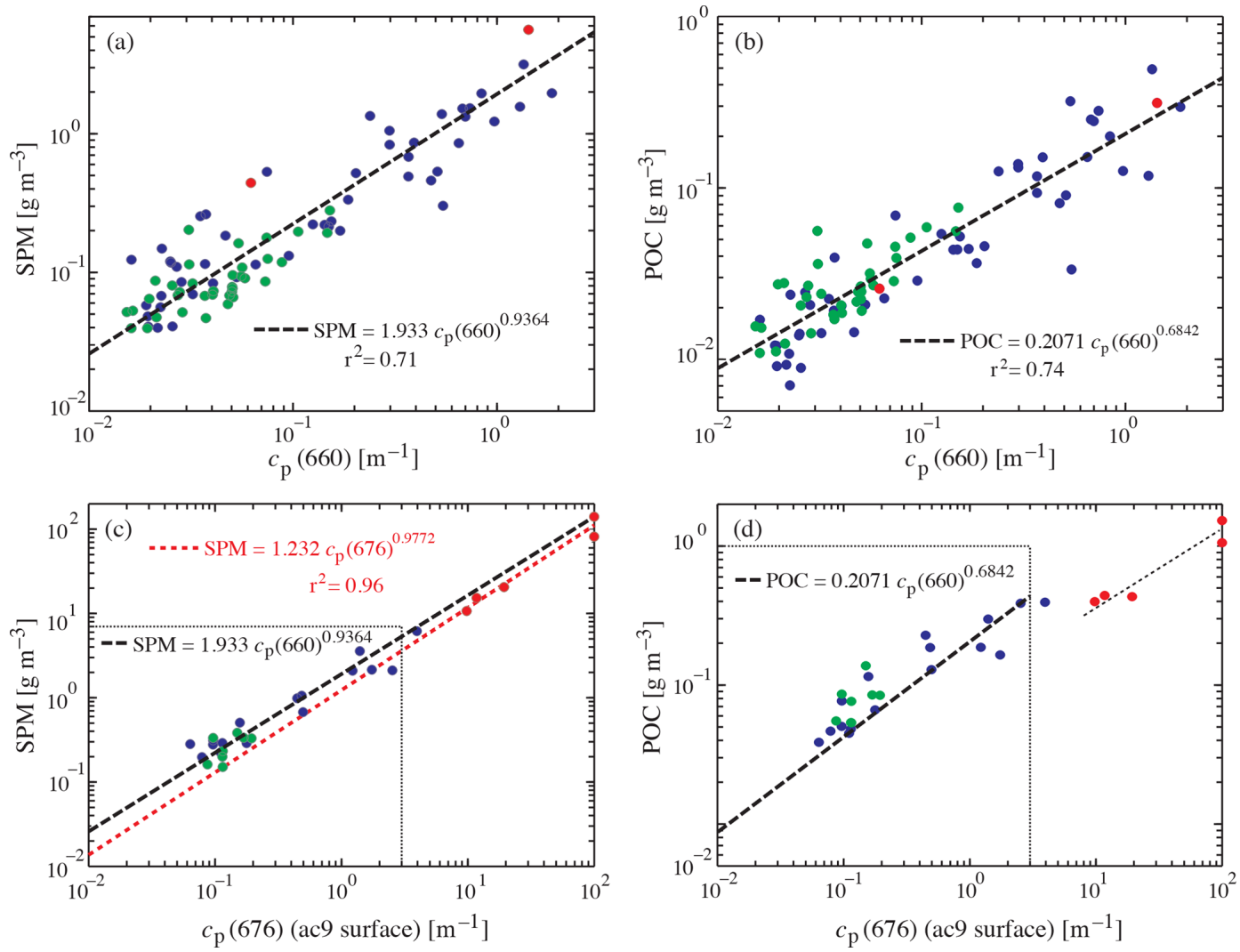

Figure 6. SPM and POC as a function of particulate beam attenuation coefficient at $660 \mathrm{~nm}$ based on measurements from CCGS Amundsen during the MALINA expedition in 2009 (a-b) and as a function of the particulate beam attenuation coefficient at $676 \mathrm{~nm}$ measured with the AC-9 from the barge (c-d) (the latter data contain only surface samples). The dotted squares in (c) and (d) indicate axis limits in (a) and (b), respectively. The colors of the data points indicate POC/SPM categories: mineral dominated (red), mixed (blue), and organic dominated (green).

This corresponds to $c_{\mathrm{p}}(660)$ values up to about $3.1 \mathrm{~m}^{-1}$; however, the highest measured $c_{\mathrm{p}}(660)$ where WET Labs CStar measurements were made (but not accompanied by SPM sampling) was $8.8 \mathrm{~m}^{-1}$ (at a depth of $10 \mathrm{~m}$ at station 394), which according to Eq. (2) would correspond to SPM of about $14.8 \mathrm{~g} \mathrm{~m}^{-3}$. For the purpose of examining SPM patterns we extend the use of Eq. (2) beyond the maximum measured SPM. A similar nonlinear least-squares regression analysis that included the highest observed SPM values and corresponding beam attenuation values measured at $676 \mathrm{~nm}$ using a WET Labs AC-9 resulted in a very good fit and a trend line approximating that of the extrapolation of Eq. (2) (Fig. 6c). This supports the assumption that the estimation of SPM from beam attenuation measurements can be reasonably well extended to cover the broader range of values measured with the WET Labs C-Star, thus being valid from the very clear open ocean to the highly turbid estuarine waters.

The situation is different for the POC vs. $c_{\mathrm{p}}(676)$ regression. Coincident observations of POC and $c_{\mathrm{p}}(676)$ reveal a tendency of POC to level off at the very high attenuation values (Fig. 6d). These high $c_{\mathrm{p}}(676)$ values were all observed from the barge in the shallow estuarine waters of the
Mackenzie River mouth (Doxaran et al., 2012). As the particle assemblages within these coastal waters are dominated by mineral particles, a weak relationship between POC and $c_{\mathrm{p}}$ is expected. However, within the POC range up to about $0.45 \mathrm{~g} \mathrm{~m}^{-3}$ and $c_{\mathrm{p}}(660) \leq 3 \mathrm{~m}^{-1}$ covered by ship-based observations (Fig. 6b), which included only organic-dominated and mixed particle assemblages (POC/SPM $\leq 25 \%$ ), both $c_{\mathrm{p}}(660)$ and $c_{\mathrm{p}}(676)$ are well represented by Eq. (3). This covers the range of $c_{\mathrm{p}}(660)$ observed along all the ship-based transects (Fig. 1).

\subsection{SPM distributions on the shelf, slope, and beyond}

The large range in concentration and composition of suspended particle assemblages (Figs. 5 and 6) collected as a part of the MALINA dataset allowed the determination of empirical relationships for estimating SPM and POC from $c_{\mathrm{p}}(660)$ (Eqs. 2-3) in Canadian Beaufort Sea waters. In the following, SPM distributions in the Canadian Beaufort Sea are investigated by applying the SPM algorithm to $c_{\mathrm{p}}(660)$ data collected during three cruises in the Canadian Beaufort Sea. These cruises include the 2-year-long projects CASES 
(2003-2004) and IPY-CFL (2007-2008) and the MALINA project in August 2009, which altogether cover a wide range of conditions encountered during the open-water season in the Canadian Beaufort Sea. Additionally, $c_{\mathrm{p}}(660)$ data from four deep casts in the Canada Basin collected during the JOIS expedition in September 2009 are examined to show conditions further away from the shelf break (Fig. 1).

Here, we focus on the cross-section plots for transect lines 100, 300, and 600 only (Fig. 1). These transect lines have also been repeatedly measured during other field campaigns (e.g., Carmack et al., 1989; Tremblay et al., 2011; Lansard et al., 2012; Mol et al., 2018). Line 100 crosses the Amundsen Gulf near its entrance from north of Cape Bathurst towards the southwestern point of Banks Island. Line 300 is a south-tonorth transect located approximately along $134^{\circ} \mathrm{W}$ and associated with Kugmallit Valley. Line 600 follows the Mackenzie Trough and provides the western border to the Mackenzie Shelf. The Mackenzie River delta is a maze of tributaries; however, the main discharge channel exits at Mackenzie Bay near the end of line 600, while the second largest channel exits at Kugmallit Bay near line 300.

Figure 7 shows the SPM fields from the three expeditions, derived from $c_{\mathrm{p}}(660)$ profiles using Eq. (2). Figure 8 provides the supporting temperature and salinity fields. Black contour lines show SPM values up to $10 \mathrm{~g} \mathrm{~m}^{-3}$ (Fig. 7f). We recall from Sect. 3.3 that both Eqs. (2) and (3) are derived from ship data and are strictly valid for $c_{\mathrm{p}}(660)$ values up to $3.1 \mathrm{~m}^{-1}$ (Fig. 6). Thus, this excludes the most mineraldominated waters on the shelf with SPM over $5.6 \mathrm{~g} \mathrm{~m}^{-3}$ and POC over about $0.5 \mathrm{~g} \mathrm{~m}^{-3}$. However, comparisons against nearshore data collected with the barge indicate that Eq. (2) for SPM is reasonably valid for a wider range (Fig. 6c). This is not the case for POC. Within the valid range $\left(c_{\mathrm{p}}(660)<\right.$ $\left.3.1 \mathrm{~m}^{-1}\right)$ the presented SPM $\left(\mathrm{g} \mathrm{m}^{-3}\right)$ fields can be converted to POC $\left(\mathrm{g} \mathrm{m}^{-3}\right)$ according to $\mathrm{POC}=0.1279 \mathrm{SPM}^{0.7307}$, which is derived from the regression analysis of POC vs. SPM data.

Elevated SPM values were generally present in shelf surface waters and associated with a lower salinity surface layer or plume. The highest values were seen nearest to the shore in shallow waters, indicating the riverine origin. SPM in the surface layer decreased past the shelf break, often reaching very low values, except within the northwest-flowing Mackenzie River plume during the 2004 CASES and 2009 MALINA expeditions (Fig. 7g, h). Clear waters with SPM ranging between 0.04 and $0.06 \mathrm{~g} \mathrm{~m}^{-3}$ were found offshore on line 300 in each of the three expeditions (Fig. 7d-f). The corresponding POC ranged from 0.01 to $0.02 \mathrm{~g} \mathrm{~m}^{-3}$. The low SPM values were especially widespread in August 2009, likely related to the high $f_{\text {SIM }}$ content (Table 1 ).

Wedges of very clear water are seen extending far onto the shelf particularly during 2009. The extension of clear waters onto the shelf as a wedge between the surface plume and the turbid near-bottom layer has been described by Carmack et al. (1989). It appears that neither particle settling from the surface plume nor the upward mixing of bottom sediments was sufficient in August 2009 to increase these clear-water values of $c_{\mathrm{p}}(660)$ above those found in deep basin surface waters. The landward extension of the clear-water layer was particularly noticeable on line 600 (Fig. 7h), which corresponds to the Mackenzie Trough, the main river channel and the most distinct surface plume feature of the transects.

\section{Subsurface nepheloid layers}

Figure 7 reveals a ubiquitous presence of intermediate nepheloid layers (INLs) extending from the Beaufort Sea continental slope. These INLs are produced primarily by resuspension of bottom sediments previously settled onto the shelf or slope and provide clear evidence for the lateral transport of suspended particles, and water, away from the shelf. Numerous INLs are seen in the upper $500 \mathrm{~m}$ of the water column throughout the Amundsen Gulf and extending into the Canada Basin; however, the variability in their depth locations is large between the profiles, revealing the complex SPM dynamics of the region (Fig. 9). Generally, the SPM of INLs in offshore waters was an order of magnitude smaller than in the benthic nepheloid layer (BNL) on the shelf, and particle concentrations decreased with distance from the shelf.

In the Mackenzie Trough (line 600), in addition to the surface river plume, two notable INLs were observed in 2004 and 2009 to extend from the shelf at depths of 100-130 and 200-250 m (Fig. 7g, h). These two INLs formed near where the 33.1 PSU isohalines intersected the shelf seafloor and immediately above and below a slightly less sloping section of the Mackenzie Trough bottom. Only the upper INL was accompanied by relatively high chl- $a$ fluorescence (Fig. 4e). However, the depths of $100 \mathrm{~m}$ and greater are beneath the euphotic layer, rendering in situ primary production negligible. Thus, these chl- $a$-containing particles likely represent laterally transported particles that originated from resuspension in shallower shelf waters.

It is important to differentiate subsurface nepheloid layers from the mainly locally formed subsurface chl- $a$ maximum (SCM) layer that is commonly present in the Canadian Beaufort Sea at depths between the 31.5 and $32.3 \mathrm{PSU}$ isohalines (Martin et al., 2010; Tremblay et al., 2011). As the SCM seems to intersect with the shelf bottom before extending into the Canada Basin (Fig. 4), the presence of relatively high chl- $a$ concentrations within subsurface nepheloid layers may however conceal the presence of minerogenic particles at the same depth. As suggested by Tremblay et al. (2011), the patterns of salinity, $c_{\mathrm{p}}(660)$, and chl- $a$ fluorescence indicate that biological production on the shelf bottom was enhanced by upwelled nutrient-rich waters and, at the time of our measurements, biogenic material was being transported seaward at a depth of 50-70 $\mathrm{m}$ in a BNL, and then INL, across the shelf break (Figs. 4 and 7c, f, g). The shelf circulation at play makes it conceivable that the transport of biogenic ma- 


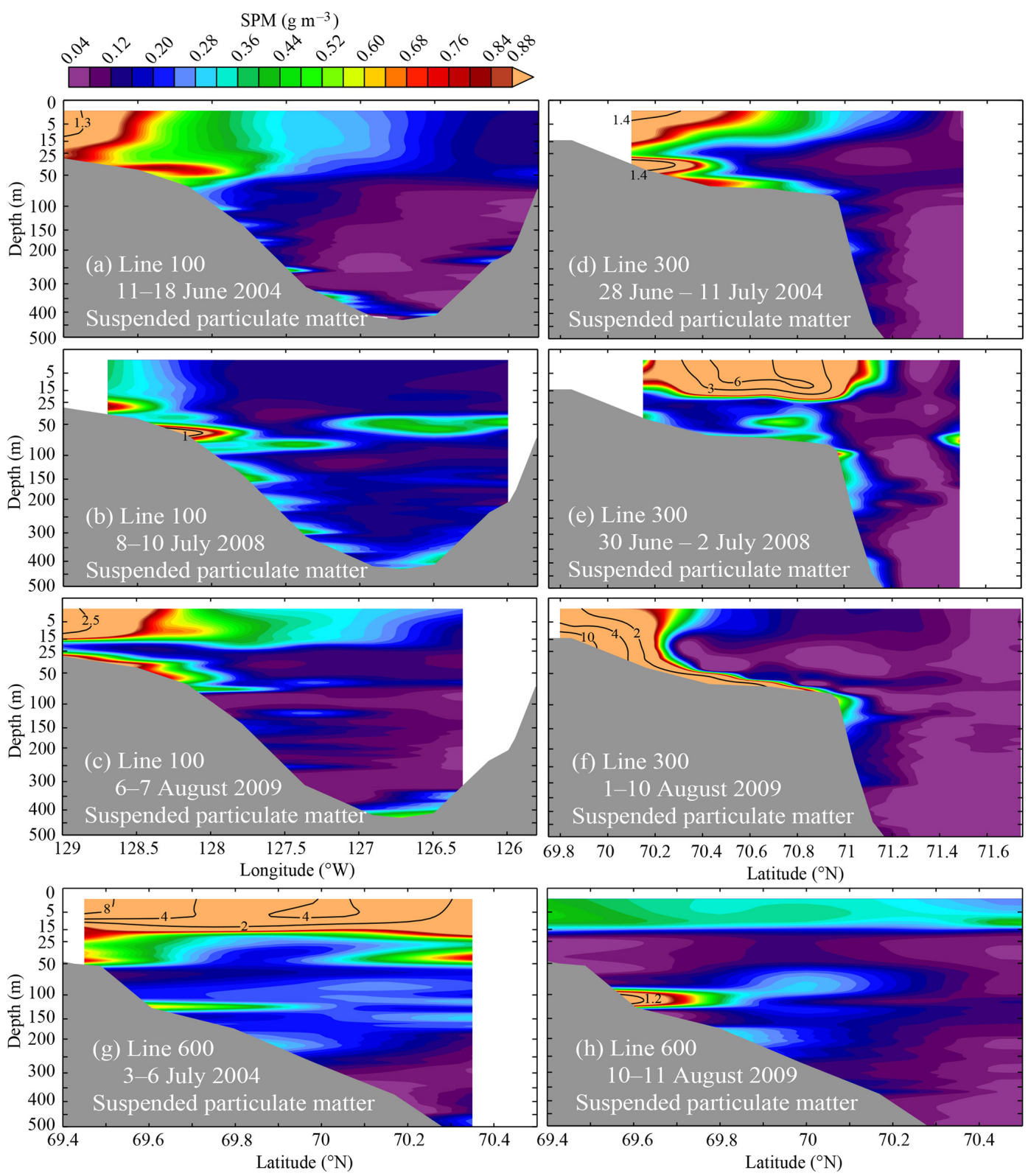

Figure 7. Concentration of suspended particulate matter, SPM, calculated from measurements of particulate beam attenuation coefficient at $660 \mathrm{~nm}, c_{\mathrm{p}}(660)$, using Eq. (2) for lines 100, 300, and 600 during different field campaigns in 2004, 2008, and 2009, as indicated.

terial produced on the shelf, including resuspension of settled particles originating from an earlier bloom (e.g., ice algae), could play some role in the formation and maintenance of the SCM in the off-shelf region.

Beneath a depth of $500 \mathrm{~m}$, the vertical profiles of SPM still showed numerous INLs and the decrease in SPM beneath or above INLs (Fig. 9), which rules out turbulent mixing and suggests lateral advection in the formation of this SPM structure. Generally, however, the particle concentration at specific depths decreased as bottom depth increased as it also relates to the distance from the shelf break. This decrease is approximately exponential, with distance from the shelf break indicating horizontal spreading. In waters less than $3000 \mathrm{~m}$ deep located on the continental slope and rise, the SPM began to increase with depth from about the mid-depth of the water column, which had the clearest waters. The thickness of these BNLs ranged from $\sim 200 \mathrm{~m}$ (station 340) to over $1000 \mathrm{~m}$ (Fig. 9). Past the $3000 \mathrm{~m}$ bottom depth, BNLs were essentially absent with the clearest waters found close to the bottom as may also be the case for the Canada Basin abyssal plain (Hunkins et al., 1969). Near-bottom SPM values based on $c_{\mathrm{p}}(660)$ were $\sim 2 \times 10^{-3} \mathrm{~g} \mathrm{~m}^{-3}$ at the station CB-27 and decreased to $\sim 1 \times 10^{-3} \mathrm{~g} \mathrm{~m}^{-3}$ at $3500 \mathrm{~m}$ at CB$21\left(74.0042^{\circ} \mathrm{N}, 139.8699^{\circ} \mathrm{W}\right.$, i.e., $113 \mathrm{~km}$ north of $\left.\mathrm{CB}-27\right)$ 


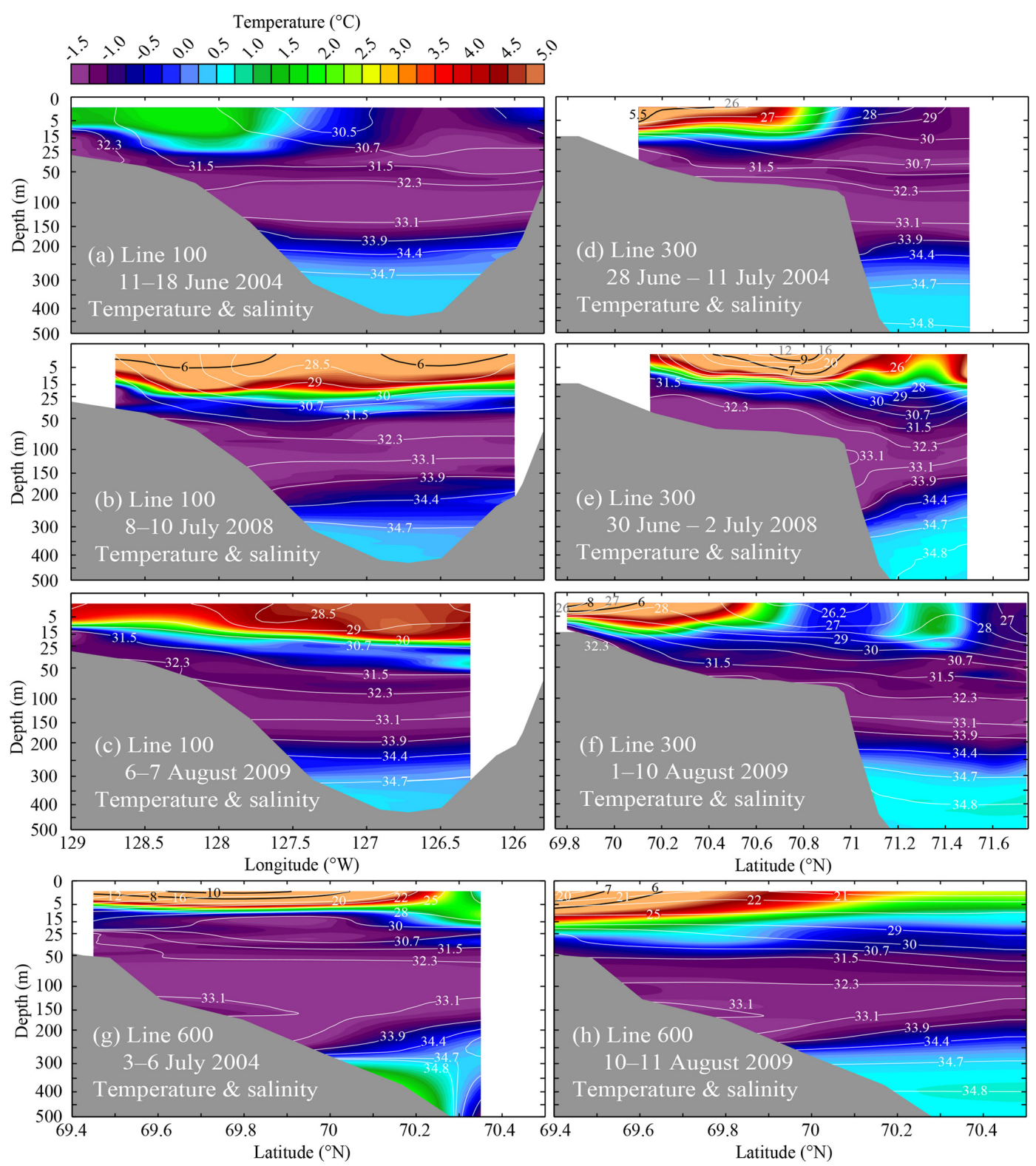

Figure 8. As Fig. 7 but for measurements of water temperature (colors) and salinity (contour lines).

on 9 October 2009. Thus, basin waters agreed with the two types of profiles described in Hunkins et al. (1969): first, in waters with bottom depths less than about $3000 \mathrm{~m}$ the SPM had minimum values roughly at mid-depths of the water column and then increased towards the bottom forming a cshaped profile, and second, in waters exceeding $3000 \mathrm{~m}$ in depth the SPM reached minimum values near the bottom.

A notable INL at stations CB-23, CB-27, and CB-21 was spreading in the layer immediately below the isopycnal surface where the potential density anomaly $\sigma_{\theta}$ reached $28.096 \mathrm{~kg} \mathrm{~m}^{-3}$ or the salinity reached 34.956 (Fig. 9). This was the deepest INL (below which no INLs were observed) extending to the Canada Basin abyssal plain at the top of the adiabatic Canada Basin bottom water layer at a depth of $\sim 2500-2700 \mathrm{~m}$ (Timmermans et al., 2003). The depth where the INL occurred varied between the stations. The maximum SPM within the INL at a depth of $2470 \mathrm{~m}$ at station CB-23 was $0.0126 \mathrm{~g} \mathrm{~m}^{-3}$. At CB-27 the maximum was $8.2 \times 10^{-3} \mathrm{~g} \mathrm{~m}^{-3}$ at $2600 \mathrm{~m}$ (Fig. 9). The SPM levels above the INLs (with $\sigma_{\theta}=28.095$ ) were 0.010 and $0.027 \mathrm{~g} \mathrm{~m}^{-3}$, respectively. Given that the INL depth increased by $130 \mathrm{~m}$ over the $128 \mathrm{~km}$ distance that separated the two stations, the INL descent rate was about $1 \mathrm{~m} \mathrm{~km}^{-1}$. A thinner $(50 \mathrm{~m}$ thick) and weaker INL with a maximum SPM of $3.2 \times 10^{-3} \mathrm{~g} \mathrm{~m}^{-3}$ at $2656 \mathrm{~m}$ was observed at CB-21 (Fig. 9d). Beneath this interface the potential temperature was uniform with depth, 

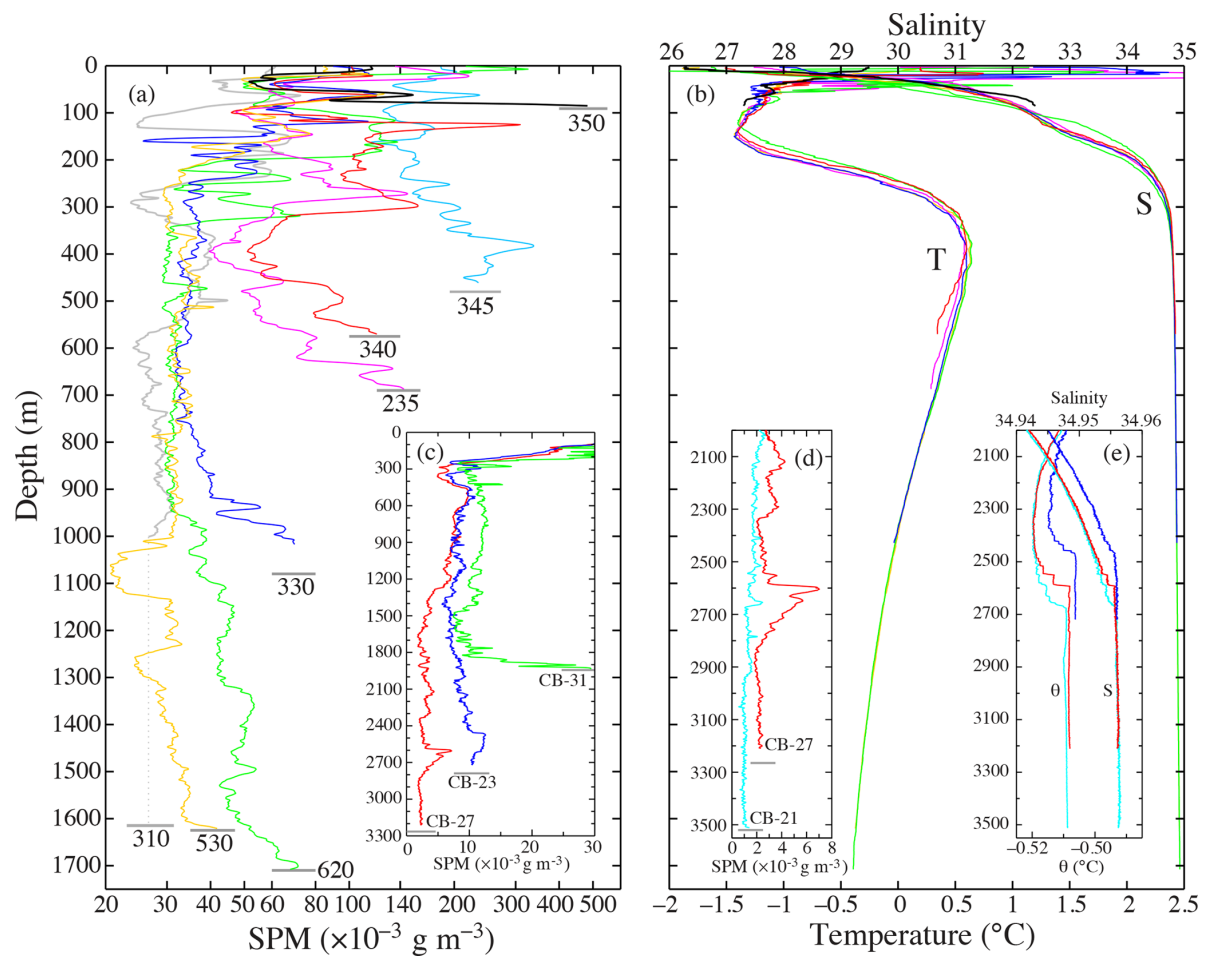

Figure 9. Vertical profiles of (a) suspended particulate matter, SPM, calculated from particulate beam attenuation coefficient at $660 \mathrm{~nm}$, $c_{\mathrm{p}}(660)$, and (b) temperature, $T$, and salinity, $S$, at selected "deep" stations. Inserts (c) and (d) show transmissometer data (converted to SPM using Eqs. 1-2) that were collected in the Canada Basin during 21-23 September 2009 and made available by the Beaufort Gyre Exploration Program based at the Woods Hole Oceanographic Institution in collaboration with researchers from Fisheries and Oceans Canada at the Institute of Ocean Sciences. Insert (e) shows a close up of the potential temperature, $\theta$, and $S$ for CB-23, CB-27, and CB-21 at the interface to the Canada Basin Bottom Water layer. Grey horizontal lines indicate bottom depths and are underlain by station numbers (see Fig. 1 for locations).

thereby marking a transition to the adiabatic Canada Basin bottom water layer (e.g., Timmermans et al., 2003). Assuming that the particles in the INL were from the bottom layer of CB-31 (depth of $1920 \mathrm{~m}$ with $\sigma_{\theta}=28.093 \mathrm{~kg} \mathrm{~m}^{-3}$ ), then the transport of particles from the bottom of station CB-31 to the INL at station CB-23 requires a $560 \mathrm{~m}$ increase in depth over a $100 \mathrm{~km}$ distance. This assumption of a northwestward flow direction of particles may not be valid because the deep circulation in the Canada Basin is thought to be a cyclonic gyre that follows bathymetric contours (e.g., Holland et al., 1996). Nevertheless, such transport of particles crosses isopycnal surfaces, suggesting ongoing particle settling in addition to advective transport.

\subsection{Environmental forcing and oceanographic conditions}

As is evident, SPM is not a conservative property of a water mass but undergoes settling or resuspension at rates that are dependent on particle composition and size and water dynamics. Consequently, in this section, the environmental forcing and oceanographic conditions during each of the three expeditions are first described and contrasted. Then, in
Sect. 3.6, the observed patterns of the SPM fields are compared and discussed in the context of these oceanographic conditions, and in particular as these patterns relate to river runoff, sea ice melt, and wind.

\subsubsection{River discharge and sea ice conditions}

The Mackenzie River discharge has large seasonal and interannual variability (e.g., McClelland et al., 2012). Similarly, sea ice concentration on the shelf undergoes large variability (Galley et al., 2008). This is also evident when comparing daily Mackenzie River discharge rates and ice concentrations on the shelf for the years 2004, 2008, and 2009 (Fig. 10). Although the seasonal trend follows a predictable overall pattern, discharge rates during the open-water season show significant day-to-day variation, while the timing of landfast ice breakup, wind forcing, and the large-scale circulation in the Beaufort Sea affect ice concentrations. The three field expeditions were conducted during different times of the annual cycle with noticeable differences in the Mackenzie River discharge (Fig. 10). The CASES 2004 cross-shelf transects were conducted a few weeks after ice breakup and the freshet. The spring freshet occurred later in 2004 with a sharp peak pulse 

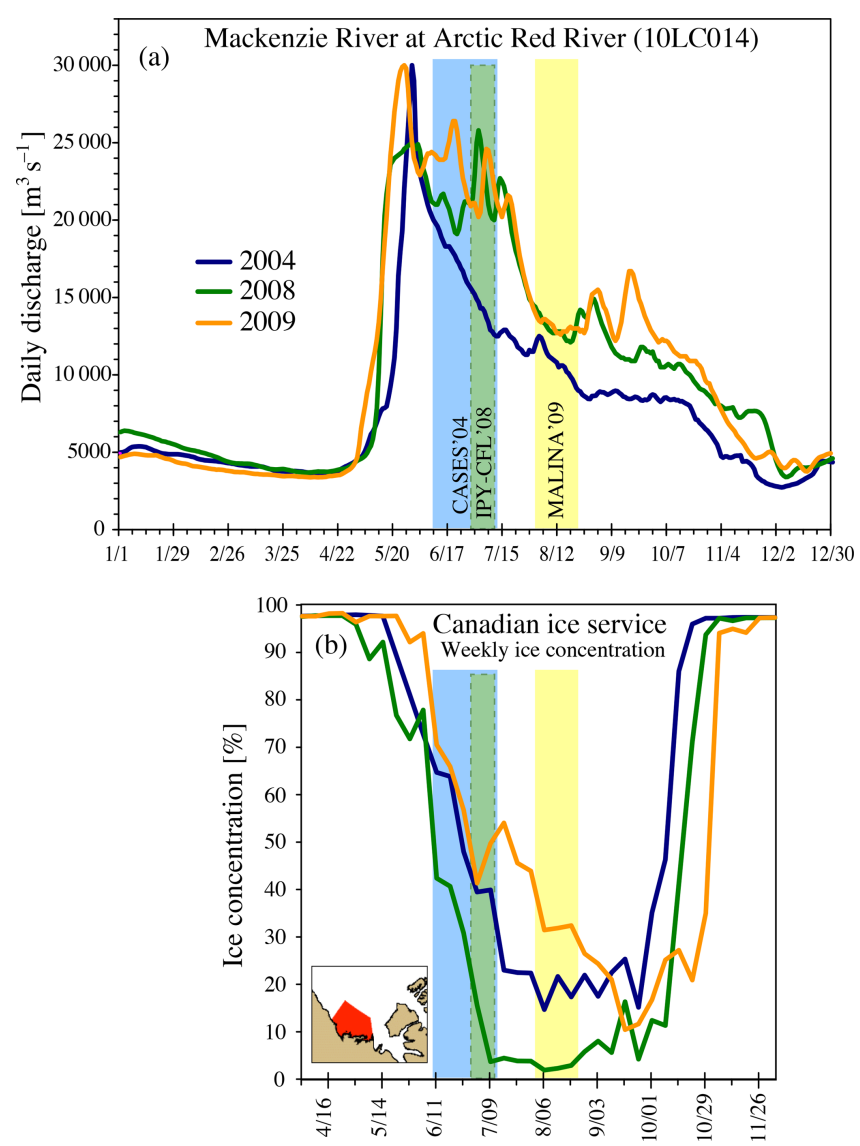

Figure 10. (a) Daily discharge for the Mackenzie River at the Arctic Red River location (10LC014). Data obtained from Environment Canada. (b) Weekly ice coverage for the Mackenzie Shelf area calculated using IceGraph 2.0 provided online by the Canadian Ice Service. The distributions of sea ice types are provided in Fig. S4. Time periods for the three expeditions considered in this study are also indicated in color shades. The $x$-axis labels are dates expressed in the format of month/day and are spaced 4 weeks apart.

that reached a higher level than during the other years considered. In 2004, the discharge decreased rapidly after the freshet so that the lowest (of the 4 years) annually averaged discharge occurred. The condition with the highest discharge rates was encountered during the IPY-CFL 2008 transect cross-section sampling as late as in early July, when ice concentrations on the shelf were unusually low (around 10\%). In contrast, the MALINA 2009 sampling occurred later in the season (August) with conditions characterized by comparatively high $(30 \%)$ sea ice concentrations on the shelf.

The buoyant freshwater released from the melting sea ice competed for surface space with river water, thus affecting plume dynamics and the ability of the plume to keep particulate matter in suspension. As was also the case during CASES in June-July 2004 (Lansard et al., 2012), the freshwater composition in the surface layer on the Mackenzie Shelf during MALINA was a mixture between river runoff (meteoric water) and sea ice meltwater (Fig. 2a). Table 1 provides information on surface salinity and the contribution of freshwater sources measured at the same geographical locations during both CASES and MALINA. Compared to MALINA, river runoff during CASES resulted in lower surface salinity and contributed to a much larger fraction of the freshwater in the southern half of the Mackenzie Shelf. Station 320 located past the shelf break, however, indicates fresher conditions during MALINA due to a higher sea ice meltwater contribution. In contrast to the river waters, sea ice meltwater typically contains little particulate matter and CDOM (e.g., compare Fig. 4b, d, f). However, significant near-surface particle enrichment was observed, which was associated with meltwater originating from multi-year ice (Bélanger et al., 2013). During MALINA, numerous multiyear ice floes had drifted into the southeastern Beaufort Sea where they were melting in place (Figs. S1 and S4 in Supplement).

\subsubsection{Wind forcing}

The large freshwater inputs to the Mackenzie Shelf during summer result in strong vertical stratification and a vertically sheared two-layer circulation (Fig. 3) (Carmack and Macdonald, 2002; Carmack and Chapman, 2003; Mol et al., 2018). This estuarine circulation is reflected in the patterns of SPM across the shelf (Fig. 7). Sustained easterly alongshelf winds, particularly when strong, are known to cause offshore Ekman transport of shelf surface waters, thereby generating upwelling of deeper nutrient-rich water of Pacific origin onto the shelf (Carmack and Kulikov, 1998; Williams et al., 2006, 2008; Yang, 2009). The high salinity observed during the MALINA expedition in Kugmallit Valley (line 300), Mackenzie Trough (line 600), and near the coast west of $140^{\circ} \mathrm{W}$ indicated the occurrence of upwelling (Fig. 2). During westerly winds, onshore Ekman transport will generate downwelling flow on the shelf (Dmitrenko et al., 2016). During westerly or weak winds, the river plume turns right to flow eastward along the coast of Tuktoyaktuk Peninsula (Carmack and Macdonald, 2002). Relaxation or reversal of either of these winds will cause return flow to occur towards or from the shelf. Furthermore, strong winds, and brine released from ice formation during late fall and winter, promote vertical mixing and may mix shallow shelf waters to the bottom (e.g., Carmack and Macdonald, 2002; Forest et al., 2007).

The wind vectors reveal a predominance of easterly winds during our study periods in 2004 and 2008-2009 often with a southward component resulting in an along-shelf wind component (Fig. 11a).

The predominance of easterly winds is also a driving force behind the large-scale anticyclonic circulation of the Beaufort Gyre and its ice cover. The occasional reversals of the Beaufort Gyre are related to transient synoptic weather patterns (Asplin et al., 2012) that also affect the circulation on 

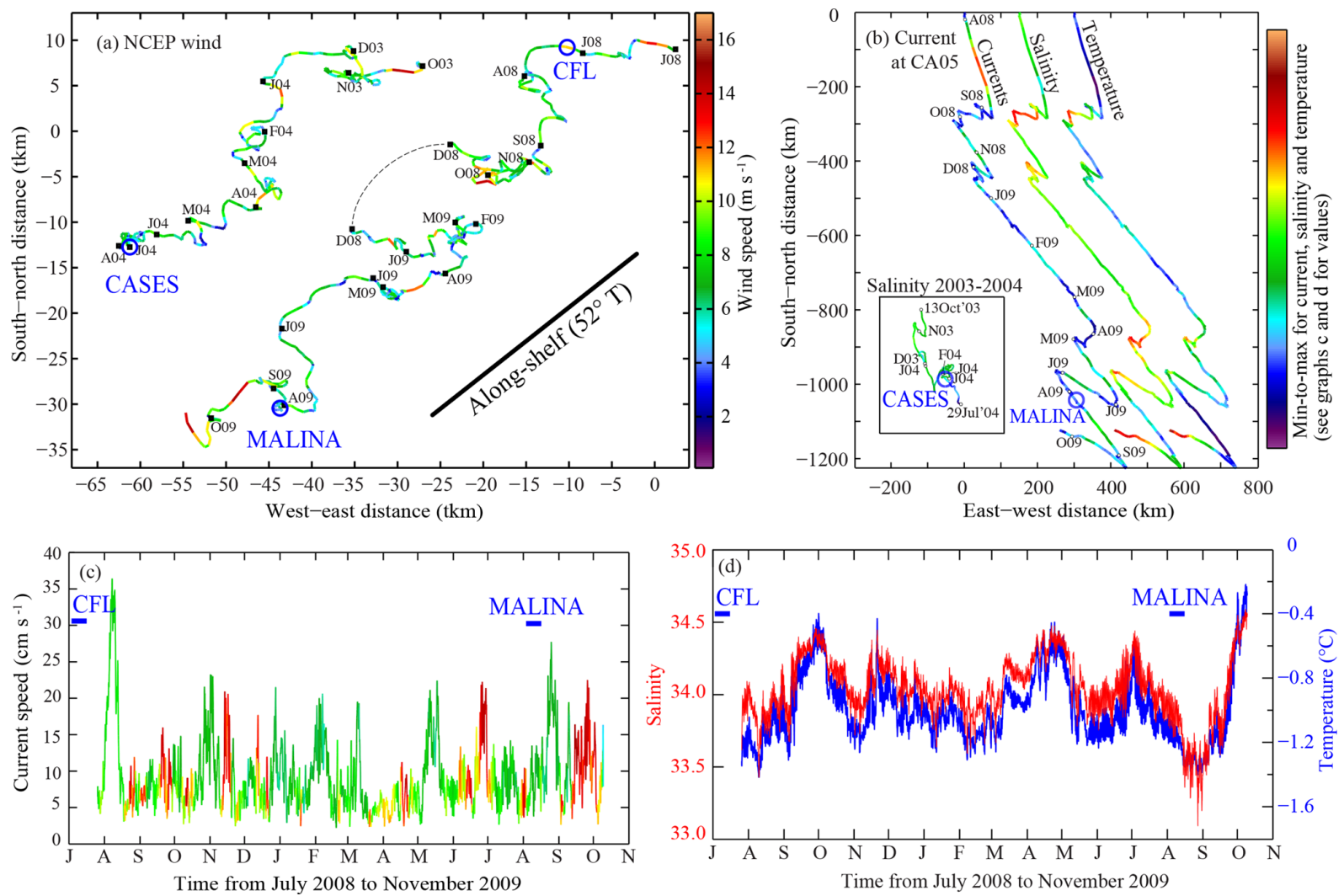

Figure 11. Progressive vector plots of (a) daily average wind (NCEP, $10 \mathrm{~m}$ ) and (b) currents from mooring CA05, with am inset for 20032004 CASES data. Colors in (a) indicate daily average wind speeds shown in the color bar. The black squares in (a) and (b) indicate the start of each month (the first letter of month followed by year, e.g., D03 stands for December 2003), while the blue circles show the approximate times of the ship-based transect sampling across the Mackenzie Shelf break used in this study. The black line shows the direction along the shelf break referenced to true north. In (b), the same vector plot for currents is shown three times, but the colors of each plot indicate current speed, salinity, or temperature as denoted next to the lines and shown in more detail in (c) and (d). For the inset in (b) showing 2003-2004, the colors indicate salinity as denoted. Time series for 2008-2009 for (c) current speed (colors are current directions), (d) salinity (red), and temperature (blue) at a depth of $178 \mathrm{~m}$.

the shelf. Two notable periods dominated by westerly winds occurred during the month of October 2008 and during December 2008 to the end of January 2009. Typically the westerly wind episodes were characterized by relatively low wind speeds.

The wind conditions prior to the ship-based expeditions (marked by blue circles) are shown in Fig. 11a. During JuneJuly 2004 (CASES) the wind speed ranged from 2 to $8 \mathrm{~m} \mathrm{~s}^{-1}$ with a variable direction. IPY-CFL sampling (late June and early July 2008) overlapped with CASES in terms of time of year; however, winds were notably different with a month of easterly winds prior to the sampling. The conditions leading up to the MALINA expedition in August 2009 are characterized by $<10 \mathrm{~m} \mathrm{~s}^{-1}$ winds at directions inducing the upwelling in June and most of July, but with a turn to northerly winds during the first part of July, which probably were a contributing factor keeping sea ice on the shelf. Winds turned to easterly (upwelling inducing) for the last week of July with wind speed $>8 \mathrm{~m} \mathrm{~s}^{-1}$. Winds during the MALINA expedi- tion were comparatively weak $\left(<6 \mathrm{~m} \mathrm{~s}^{-1}\right)$ with variable direction.

\subsubsection{Evidence of upwelling and relaxation}

Current speeds and directions were measured at a depth of $178 \mathrm{~m}$ on the CA05 mooring in 2008-2009 (and at $250 \mathrm{~m}$ in 2003-2004) (Fig. 11b). This depth corresponded to the location of the base of the eastward-flowing shelf break current (Fig. 3a). The currents at this depth on the slope were found to have two distinct modes: (i) along-shelf current that followed the isobaths towards the southwest (i.e., $\sim 140^{\circ}$ ) and (ii) northeastward cross-shelf current $\left(\sim 300^{\circ}\right)$. Interestingly, the shift between the two modes was very brief, occurring within only a few hours.

The long periods (i.e., from October to November 2008, from December 2008 to April 2009, and from May to June 2009) of along-shelf southwestward currents at a depth of $178 \mathrm{~m}$ at mooring CA05 (Fig. 11b) were related to pe- 
riods with either weak winds or westerly winds (Fig. 11a). Episodes with cross-shelf currents occurred on five occasions in the period between August 2008 and October 2009 (Fig. 11b). In addition, a brief period of change in direction occurred during late July and the first few days of August 2009, likely associated with the change in wind direction to easterly during the last week of July. The time series collected during 2003-2004 show only a minor crossshelf flowing event around the beginning of November. Each episode with cross-shelf currents, with the exception of November 2003 (the location of the moored instrument was deeper and further east compared to 2008-2009), was associated with increases in salinity, temperature, or both, which is an indication of upwelling. All of these events are directly linked to periods with strong easterly along-shelf winds (Fig. 11a), highlighting the likely role of the wind in forcing upwelling. During 2009, the salinity reached up to 34.5 PSU (Fig. 11d), which corresponds to an "effective depth" (see Fig. 3 in Carmack and Kulikov, 1998) of about $300 \mathrm{~m}$, indicating a vertical displacement of $\sim 120 \mathrm{~m}$ compared to a representative offshore location. Note, however, that the recorded salinity rarely decreased below 33.5 PSU, which in itself corresponds to an effective depth of more than $200 \mathrm{~m}$. After the abrupt termination of each upwelling event, temperature and salinity decreased towards pre-upwelling values. Some of the lowest salinity values at $178 \mathrm{~m}$ were encountered at the time of the MALINA expedition during August 2009 and associated with downwelling return flow on the Mackenzie Shelf (Fig. 11d).

Episodes of high along-shelf current speeds (dark green in Fig. 11c), such as at the end of the MALINA expedition in late August 2009, but also in November 2008, February, May, and July 2009, were generally associated with reductions in salinity and temperature at the CA05 mooring and perhaps also linked to shelf break transport of SPM with downwelling flow.

\subsection{Effects of river runoff and sea ice melt on SPM distributions on the shelf}

\subsubsection{River plume variability}

Wind forcing largely controls the flow direction of the Mackenzie River plume. Due to the size and shape of the Mackenzie Shelf, the most likely direction for the Mackenzie River plume to spread significant distances past the shelf break is to the northwest (Doxaran et al., 2012). During the spring freshet in June 2009, sustained easterly alongshelf winds caused the flaw-lead polynya to widen along the Mackenzie Shelf and a turbid river plume extended northwestward from the landfast ice to the pack ice (Fig. S2). The MALINA sampling occurred during a time of transition from a northwestward plume (during easterly winds) towards a Coriolis-forced right-turning plume flowing eastward along the coast. Plumes of both directions are visible in MODIS satellite images for the period of the MALINA expedition (Doxaran et al., 2012; Forest et al., 2013). By 26 July 2009, the plume was clearly seen extending out past the tip of Cape Bathurst. The sampling along lines 600 and 700 was conducted during the first half of August 2009, following a 2week period of easterly winds (Fig. 11a). By mid-August only very weak features remained from the northwestward plume. Notably, both river discharge and ice concentrations on the shelf were reduced by half during the period of 1 month (Fig. 10).

Figures $7 \mathrm{~g}, \mathrm{~h}$ and $8 \mathrm{~g}, \mathrm{~h}$ show the river plume extending northwest along the Mackenzie Trough (line 600). The Mackenzie River plume occupied a layer about $15 \mathrm{~m}$ thick at the sea surface in both July 2004 and August 2009. A sharp decrease in SPM was found immediately below this layer. The surface plumes had low salinity, high meteoric water fractions (Table 1 and Fig. 2a), and high CDOM fluorescence (Fig. 4f), at least in 2009, and a high $<1 \mu \mathrm{m}$ particle volume fraction (Fig. 5c, d), indicating a riverine origin. Interestingly, particle concentrations differed markedly for the two years compared. In 2004, high levels of SPM extended the full length of the transect with values reaching $4 \mathrm{~g} \mathrm{~m}^{-3}$ as far as $70^{\circ} \mathrm{N}$. In contrast, in 2009 the SPM values observed in the plume were only about $10 \%$ of the 2004 values but still distinctly noticeable because the plume overlaid a layer of very clear water. Also, the waters beneath the river plume in 2004 were significantly more turbid compared to 2009 , probably due to settling of particles from the plume.

Although the timing of the transect measurements in 2004 and 2009 was a month apart, overall conditions on the shelf were not markedly different. Easterly winds were weak in both cases (Fig. 11), ice coverage on the shelf was $30 \%-$ $40 \%$, and the river discharge was $\sim 13000-14000 \mathrm{~m}^{3} \mathrm{~s}^{-1}$ during both years (Fig. 10). Moreover, the cross sections along lines 100 (Fig. 7a, c) and 300 (Fig. 7d, f) show very similar features and particle concentrations during the two years. The differences between the two situations can be attributed to the seasonal timing. The 2004 transects were measured in early July soon after the breakup of the landfast sea ice cover and the surge of backed-up river waters across the delta and estuary. In contrast, the 2009 measurements were conducted much later in the season after landfast ice breakup. Consequently, in 2004 the surface plume was likely conditioned by a greater initial SPM discharge at the river mouth and by a higher momentum compared to 2009 so that it was capable of keeping more particles in suspension for a longer distance, including larger-sized particles if present. MODIS imagery of sea-surface temperature for 2 July 2004 (Fig. S3) highlights this river plume inertia.

\subsubsection{Surface versus near-bottom cross-shelf SPM distributions}

Comparatively high levels of SPM were found along line 300 (Kugmallit Valley) near the shelf bottom in August 2009 
with particularly high values extending across the shelf (Fig. 7f). On line 600 (Fig. 7h), a nepheloid layer with $\mathrm{SPM}>0.001 \mathrm{~g} \mathrm{~m}^{-3}$ formed near the 33.1 PSU isohaline at a depth of $\sim 100 \mathrm{~m}$. It was accompanied by a strong chl$a$ fluorescence signal (Fig. 4e). Elevated near-bottom and shelf break SPM values were also observed during CASES and IPY-CFL (Fig. 7d, g). Such SPM patterns are indicative of downwelling return flow from the shelf after upwellinginducing wind conditions relaxed. The presence of sea ice and its meltwater on the shelf during August 2009, as seen from the low surface temperatures and salinities at $\sim 70.9^{\circ} \mathrm{N}$ (Fig. 8f) and high meltwater fractions (Fig. 2a and Table 1), can explain the containment of the spreading of the plume along line 300 (Fig. 7f). High particle settling rates from a slow moving or stagnant river plume may in turn explain the elevated near-bottom SPM, which then could be transported along the shelf bottom with the return flow of the upwelled waters.

A contrasting situation is provided by the conditions observed along line 300 during June-July 2008 (IPY-CFL study) (Figs. 7e and 8e). During the IPY-CFL, ice coverage on the shelf was low (Fig. 10b) and upwelling-inducing winds prevailed throughout June and early July (Fig. 11a). Consequently, the two compared SPM sections along line 300 differed markedly (Fig. 7e, f). As seen in Fig. 7e, in 2008 the turbid surface river plume spread northward past the shelf break. At the same time, the near-bottom turbidity was low likely owing to conditions resulting from upwelling, evidenced by the high salinity of the shelf-bottom water and the extent of the surface plume (see Fig. 8e). This offshore surface flow was made possible by the absence of sea ice and ice meltwater (buoyancy forcing) and wind-driven Ekman transport.

The low SPM values were especially widespread in August 2009 (MALINA) with wedges of very clear water extending far onto the shelf. The conditions encountered during MALINA differed from expeditions in previous years particularly in terms of sea ice coverage (Fig. 10b). The breakup of the landfast ice on the shelf occurred relatively late and ice floes were not readily transported away from the shelf due to the northerly and, then later, weak winds (Fig. 11a). Furthermore, multi-year ice extended further south compared to the two other years considered in this study (Fig. S4). At around $70.5^{\circ} \mathrm{N}$ on line 300 , which coincides with the northward extent of the river plume and rapid decrease in water column SPM levels (Fig. 7f), the surface salinity decreased below $27 \mathrm{PSU}$ and the temperature was $<5^{\circ} \mathrm{C}$ (Fig. 8f) with over $>70 \% f_{\text {SIM }}$ fraction of the freshwater (Fig. 2a). As sea surface salinity remained low for the length of line 300 (Fig. 8f), we argue that the meltwater from this ice influenced the low SPM levels in the shelf waters by increasing the stratification, reducing vertical mixing and hindering the northward spread of the particle-rich river plume.

Another contrasting situation is seen in the Amundsen Gulf along line 100 (Fig. 7a-c) where differences in con- ditions between the years can be explained by the presence or absence of sea ice and the history of wind forcing as it relates to SPM transport from the shelf. Whereas ice-free and comparatively clear surface waters were present in 2008 (Fig. 7b), turbid (i.e., high $c_{\mathrm{p}}(660)$ and SPM) surface waters extended across the Amundsen Gulf in 2004 and 2009 (Fig. 7a, c), and the surface was furthermore partially ice covered in June 2004 (Fig. S4a). The temperature and salinity fields, however, showed only modest differences between conditions in 2004, 2008, and 2009, and the water column remained vertically stratified throughout the transect line (Fig. 8a-c). This suggests that the turbid surface waters in 2004 and 2009 were caused by the advection of shelf waters containing particles that originated from the Mackenzie River and/or from bottom resuspension in shallow shelf waters closer to the shore. This is corroborated by the observed high meteoric water fractions in 2004 and 2009 (Table 1) and the high fraction of $<1 \mu \mathrm{m}$ particles in the surface waters in 2009 (Fig. 5d). The equally fresh but clear surface layer in July 2008, after a long period of easterly winds (Fig. 11a) and consequent westward circulation on the shelf (Mol et al., 2018), was however associated with sea ice meltwater with a relatively low concentration of particles.

The observations that $f_{\mathrm{MW}}$ at stations 110 and 140 in July 2008 (IPY-CFL) were of similar magnitude to those observed during CASES and MALINA may be an indication of the importance of resuspension in the supply of SPM to surface water.

Tremblay et al. (2011) discussed the conditions in 2008, as well as nutrient dynamics, leading up to the high primary productivity observed in the Amundsen Gulf during the summer of 2008. The productivity of the SCM is generally proportional to the concentration of chl $a$ and limited by light and nutrient availability (Martin et al., 2010). Tremblay et al. (2011) proposed that the unusually early clearing of sea ice in 2008 was the key factor in increasing the subsurface light availability and primary productivity. However, the influence of the optical water clarity of the surface water layer was not considered. For example, Fig. 7a-c reveal that in July 2008, beneath the low-turbidity surface layer, a higher SPM in the SCM centered at the 31.5 PSU isohaline (depth of $50 \mathrm{~m}$ ) was observed compared to June 2004 and August 2009 when surface water layers were more turbid. Thus, we suggest that the cross-shelf transport of SPM in surface plumes may additionally influence primary productivity in the Amundsen Gulf by reducing light penetration.

\section{Conclusions}

The data collected in the southeastern Beaufort Sea during MALINA in August 2009 enabled the development of relationships for estimating SPM and POC from measurements of optical beam attenuation coefficient. These relationships provided, in turn, a means for obtaining a comprehensive 
view of particle concentration fields covering the full expanse of the Canadian Beaufort Sea continental margin on the basis of optical data collected during several expeditions in this region. Accompanying water sampling enabled us to conduct a detailed assessment of oceanographic conditions and particle characteristics, including freshwater sources, particle size, and composition. Our analysis revealed temporal and spatial variations in particle concentration and dynamics, which could be attributed to (i) discharge of the Mackenzie River, (ii) ice coverage and meltwater, and (iii) wind forcing.

These three factors control the estuarine-like two-layer circulation on the shelf during summer and are reflected in cross-shelf SPM patterns that suggest transport occurring mainly within a buoyant surface river plume and the bottom boundary layer.

SPM on the shelf exceeded $1 \mathrm{~g} \mathrm{~m}^{-3}$ in each of these cases. A clear water layer was also found at mid-depths on the outer shelf. Similar features were noted by Carmack et al. (1989).

The wind-driven shelf break upwelling and downwelling signals were clearly present in the CA05 mooring record for the base of the Pacific Water layer (Fig. 11b) on the continental slope at the mouth of the Amundsen Gulf (Fig. 1) at a depth corresponding to an eastward-flowing shelf break jet (Fig. 3). At a depth of $178 \mathrm{~m}$, the current was seen to follow isobaths during quiescent and downwelling-favorable conditions but switched to move cross-shelf during upwellingfavorable winds (Fig. 11a, b). Interestingly, there appeared to be two very distinct modes of flow at this depth and location along the slope. In 2009, the salinity at $178 \mathrm{~m}$ reached 34.5 PSU during the upwelling events (Fig. 11d), which corresponds to an effective depth of about $300 \mathrm{~m}$ (Carmack and Kulikov, 1998). However, in all cross-shelf transects shown in Fig. 8, salinities of at least 32.3 PSU were found on the shelf at a depth of $60-80 \mathrm{~m}$. This salinity corresponded to the transition between Pacific Summer Water and Winter Water, which is typically found at a depth of $100 \mathrm{~m}$ in the Canada Basin (e.g., Carmack et al., 1989). The salinity on the shelf was higher than in corresponding Canada Basin waters at all times and all observed sections. Thus, this modest $20-40 \mathrm{~m}$ of (depth-equivalent) upwelling onto the shelf may represent a steady state condition linked to the generally easterly wind and anticyclonic circulation of the Beaufort Gyre.

Freshwater inputs from the Mackenzie River and the melting of sea ice resulted in surface waters being a varying mixture of $f_{\mathrm{MW}}, f_{\mathrm{SIM}}$, and $f_{\mathrm{PSW}}$, where PSW refers to Pacific Summer Water with a core salinity of 31.5 PSU. We found that the buoyant sea ice meltwater competed for space with the river plume and in contrast contained little particulate matter (and CDOM; Fig. 4), which had a significant effect on SPM distributions within the surface layer. When ice meltwater was present on the shelf during years with high ice coverage, it appeared to restrict the expansion of the surface river plume, and cross-shelf break transport of particles was consequently found to occur mainly along the shelf bottom in a benthic nepheloid layer (Fig. 7). This was a consequence of two factors: (i) the reduction in plume buoyancy driving force by the sea ice meltwater layer such that more particles carried by a slower-moving or stagnant plume were settled to the bottom and (ii) weak or westerly winds that allowed sea ice and meltwater to remain on the shelf and to initiate downwelling return flow (after relaxation of wind-induced upwelling) that could transport particles in the bottom boundary layer towards the shelf break.

Particle characteristics in surface waters differed considerably depending on the relative contributions of river runoff and sea ice meltwater. Compared to sea ice meltwater, river runoff carried significantly higher SPM loads (Fig. 7), had a particle size distribution with a higher fraction of submicron particles, a smaller POC-to-SPM ratio (i.e., more minerogenic particles), and a high CDOM content (Figs. 45 ). These differences have implications on the optical properties of the water and consequently affect the propagation of sunlight and primary productivity during the open-water season.

As the Arctic continues to warm, the open-water season is expected to become increasingly longer and the extent of multi-year ice is expected to further decline (Stroeve et al., 2014). The reduction in ice coverage in the Beaufort Sea implies an increase in SPM dynamics on the continental margin due to the associated changes in wind forcing and river discharge (Carmack et al., 2006). Greater wind and wave forcing on open waters is expected to increase particle concentrations on the shelf. However, the presence of both clear intermediate waters and highly turbid bottom waters observed on the shelf in this study highlighted interesting linkages to the effect of sea ice on river water and particle transport on the shelf, which need further study. The processes that operate within subsurface layers and ice-covered waters cannot be deciphered through satellite remote sensing, so their quantification requires in situ monitoring. Optical beam transmission is a simple yet efficient tool for mapping SPM distributions. The relationship between SPM and $c_{\mathrm{p}}(660)$ developed in this study can be applied to past and future transmissometer observations to monitor changes in SPM. Vertical measurements reaching all the way to the seafloor would be very beneficial when attempting to determine lateral SPM transport. This is typically not done due to the risk to the instruments. Furthermore, ongoing research that considers current speeds together with particle size distributions are needed in order to shed more light on particle transport and settling processes across the Beaufort Sea continental shelf and slope, which are experiencing considerable change in response to river discharge, sea ice coverage, and wind forcing. The results from this study can help evaluate numerical models, which may be used to investigate sensitivities of SPM dynamics associated with oceanographic and forcing conditions on the Mackenzie Shelf. 
Data availability. All data used in this study are available in the following online databases: Polar Data Catalogue (https://www.polardata.ca, last access: 10 April 2019), Water Survey of Canada (Environment and Climate Change Canada) (https://wateroffice.ec.gc.ca, last access: 10 April 2019)), Canadian Ice Service (Environment and Climate Change Canada) (https://www.canada.ca/en/environment-climate-change/ services/ice-forecasts-observations.html, last access: 10 April 2019)), National Centers for Environmental Prediction (NCEP) (https://www.ncep.noaa.gov, last access: 10 April 2019)), and the French national IMBER/SOLAS database (http://www.obs-vlfr.fr/proof/, last access: 10 April 2019)).

Supplement. The supplement related to this article is available online at: https://doi.org/10.5194/bg-16-1583-2019-supplement.

Author contributions. JKE drafted the paper, analyzed the data, and prepared the figures. JKE and DD collected and analyzed the SPM and POC data while RR conducted the particle size distribution sampling. BL conducted all $\delta^{18} \mathrm{O}$ sampling. All coauthors contributed to writing the paper.

Competing interests. The authors declare that they have no conflict of interest.

Acknowledgements. This study was conducted as part of the MALINA Scientific Program funded by ANR (Agence Nationale de la Recherche), INSU-CNRS (Institut National des Sciences de l'Univers - Centre National de la Recherche Scientifique), CNES (Centre National d'Etudes Spatiales), ESA (European Space Agency), and the ArcticNet Canadian Network of Centres of Excellence. Additional funding for Jens K. Ehn, Rick A. Reynolds, and Dariusz Stramski was provided by the US National Aeronautics and Space Administration (grant NNX07AR20G). Jens K. Ehn is funded by the Natural Sciences and Engineering Research Council of Canada (NSERC) Discovery Grant program. We thank the National Aeronautics and Space Administration (NASA), National Centers for Environmental Prediction (NCEP), Environment Canada, and the Beaufort Gyre Exploration Program for providing free access to data. We thank all participants on the CASES, ArcticNet, IPY-CFL, and MALINA cruises for their help and in particular all of the crew members on board CCGS Amundsen. We thank Jennifer Jackson, the one anonymous reviewer, and the editor for constructive comments on the paper.

Review statement. This paper was edited by Tina Treude and reviewed by Jennifer Jackson and one anonymous referee.

\section{References}

Asplin, M. G., Galley, R., Barber, D. G., and Prinsenberg, S.: Fracture of summer perennial sea ice by ocean swell as a result of Arctic storms, J. Geophys. Res., 117, C06025, https://doi.org/10.1029/2011JC007221, 2012.

Babin, M., Stramski, D., Ferrari, G. M., Claustre, H., Bricaud, A., Obolensky, G., and Hoepffner, N.: Variations in the light absorption coefficients of phytoplankton, nonalgal particles, and dissolved organic matter in coastal waters around Europe, J. Geophys. Res., 108, 3211, https://doi.org/10.1029/2001JC000882, 2003a.

Babin, M., Morel, A., Fournier-Sicre, V., Fell, F., and Stramski, D.: Light scattering properties of marine particles in coastal and open ocean waters as related to the particle mass concentration, Limnol. Oceanogr., 48, 843-859, 2003 b.

Barber, D. G., Asplin, M. G., Gratton, Y., Lukovich, J. V., Galley, R. J., Raddatz, R. L., and Leitch, D.: The International polar year (IPY) circumpolar flaw lead (CFL) system study: Overview and the physical system, Atmos. Ocean, 48, 225-243, https://doi.org/10.3137/OC317.2010, 2010.

Bélanger, S., Cizmeli, S. A., Ehn, J., Matsuoka, A., Doxaran, D., Hooker, S., and Babin, M.: Light absorption and partitioning in Arctic Ocean surface waters: impact of multiyear ice melting, Biogeosciences, 10, 6433-6452, https://doi.org/10.5194/bg-106433-2013, 2013.

Bishop, J. K. B.: The correction and suspended mass calibration of Sea Tech transmissometer data, Deep-Sea Res., 33, 121-134, 1986.

Bishop, J. K. B: Transmissometer measurement of POC, DeepSea Res. Pt. I, 46, 353-369, https://doi.org/10.1016/S09670637(98)00069-7, 1999.

Boss, E., Slade, W., and Hill, P.: Effect of particulate aggregation in aquatic environments on the beam attenuation and its utility as a proxy for particulate mass, Opt. Express, 17, 9408-9420, https://doi.org/10.1364/OE.17.009408, 2009.

Bricaud, A., Morel, A., and Prieur, L.: Absorption by dissolved organic matter of the sea (yellow substance) in the UV and visible domains, Limnol. Oceanogr., 26, 43-53, https://doi.org/10.4319/lo.1981.26.1.0043, 1981.

Bunt, J. A. C., Larcombe, P., and Jago, C. F.: Quantifying the response of optical backscatter devices and transmissometers to variations in suspended particulate matter, Cont. Shelf Res., 19, 1199-1220, https://doi.org/10.1016/S0278-4343(99)000187, 1999

Carmack, E. and Chapman, D. C.: Wind-driven shelf/basin exchange on an Arctic shelf: The joint roles of ice cover extent and shelf-break bathymetry, Geophys. Res. Lett., 30, 1778, https://doi.org/10.1029/2003GL017526, 2003.

Carmack, E. C. and Kulikov, E. A.: Wind-forced upwelling and internal Kelvin wave generation in Mackenzie Canyon, Beaufort Sea, J. Geophys. Res., 103, 18447-18458, 1998.

Carmack, E. C. and Macdonald, R. W.: Oceanography of the Canadian shelf of the Beaufort Sea: A setting for marine life, Arctic, 55, 29-45, 2002.

Carmack, E. C., Macdonald, R. W., and Papadakis, J. E.: Water mass structure and boundaries in the Mackenzie shelf estuary, J. Geophys. Res., 94, 18043-18055, 1989.

Carmack, E., Barber, D., Christensen, J., Macdonald, R., Rudels, B., and Sakshaug, E.: Climate variability and physical forcing of the food webs and the carbon budget on panarctic shelves, Prog. Oceanogr., 71, 145-181, https://doi.org/10.1016/j.pocean.2006.10.005, 2006. 
Cetinić, I., Perry, M. J., Briggs, N. T., Kallin, E., D’Asaro, E. A., and Lee, C. M.: Particulate organic carbon and inherent optical properties during 2008 North Atlantic Bloom Experiment, J. Geophys. Res., 117, C06028, https://doi.org/10.1029/2011JC007771, 2012.

Doxaran, D., Ehn, J., Bélanger, S., Matsuoka, A., Hooker, S., and Babin, M.: Optical characterisation of suspended particles in the Mackenzie River plume (Canadian Arctic Ocean) and implications for ocean colour remote sensing, Biogeosciences, 9, 32133229, https://doi.org/10.5194/bg-9-3213-2012, 2012.

Dmitrenko, I. A., Kirillov, S. A., Forest, A., Gratton, Y., Volkov, D. L., Williams, W. J., Lukovich, J. V., Belanger, C., and Barber, D. G.: Shelfbreak current over the Canadian Beaufort Sea continental slope: Wind-driven events in January 2005, J. Geophys. Res., 121, 2447-2468, https://doi.org/10.1002/2015JC011514, 2016.

Forest, A., Sampei, M., Hattori, H., Makabe, R., Sasaki, H., Fukuchi, M., Wassmann, P., and Fortier, L.: Particulate organic carbon fluxes on the slope of the Mackenzie Shelf (Beaufort Sea): Physical and biological forcing of shelf-basin exchanges, J. Marine Syst., 68, 39-54, https://doi.org/10.1016/j.jmarsys.2006.10.008, 2007.

Forest, A., Bélanger, S., Sampei, M., Sasaki, H., Lalande, C., and Fortier, L.: Three-year assessment of particulate organic carbon fluxes in Amundsen Gulf (Beaufort Sea): Satellite observations and sediment trap measurements, Deep-Sea Res. Pt. I, 57, 125142, https://doi.org/10.1016/j.dsr.2009.10.002, 2010.

Forest, A., Babin, M., Stemmann, L., Picheral, M., Sampei, M., Fortier, L., Gratton, Y., Bélanger, S., Devred, E., Sahlin, J., Doxaran, D., Joux, F., Ortega-Retuerta, E., Martín, J., Jeffrey, W. H., Gasser, B., and Carlos Miquel, J.: Ecosystem function and particle flux dynamics across the Mackenzie Shelf (Beaufort Sea, Arctic Ocean): an integrative analysis of spatial variability and biophysical forcings, Biogeosciences, 10, 2833-2866, https://doi.org/10.5194/bg-10-2833-2013, 2013.

Forest, A., Osborne, P. D., Fortier, L., Sampei, M., and Lowings, M. G.: Physical forcings and intense shelf-slope fluxes of particulate matter in the halocline waters of the Canadian Beaufort Sea during winter, Cont. Shelf Res., 101, 1-21, https://doi.org/10.1016/j.csr.2015.03.009, 2015.

Galley, R. J., Key, E., Barber, D. G., Hwang, B. J., and Ehn, J. K.: Spatial and temporal variability of sea ice in the southern Beaufort Sea and Amundsen Gulf: 1980-2004, J. Geophys. Res., 113, C05S95, https://doi.org/10.1029/2007JC004553, 2008.

Gardner, W. D., Mishonov, A. V., and Richardson, M. J.: Global POC concentrations from in-situ and satellite data, Deep-Sea Res. Pt. II, 53, 718-740, https://doi.org/10.1016/j.dsr2.2006.01.029, 2006.

Hill, P. S.,Boss, E., Newgard, J. P., Law, B. A., and Milligan, T. G.: Observations of the sensitivity of beam attenuation to particle size in a coastal bottom boundary layer, J. Geophys. Res., 116, C02023, https://doi.org/10.1029/2010JC006539, 2011.

Holland, D. M., Mysak, L. A., and Oberhuber, J. M.: An investigation of the general circulation of the Arctic Ocean using an isopycnal model, Tellus A, 48, 138-157, https://doi.org/10.3402/tellusa.v48i1.12044, 1996.

Honjo, S., Krishfield, R. A., Eglinton, T. I., Manganini, S. J., Kemp, J. N., Doherty, K., Hwang, J., McKee, T. K., and Takizawa, T.: Biological pump processes in the cryopelagic and hemipelagic Arctic Ocean: Canada
Basin and Chukchi Rise, Prog. Oceanogr., 85, 137-170, https://doi.org/10.1016/j.pocean.2010.02.009, 2010.

Hunkins, K., Thorndike, E. M., and Mathieu, G.: Nepheloid layers in the Arctic Ocean, J. Geophys. Res., 74, 6995-7008, 1969.

Ingram, R. G., Williams, W. J., van Hardenberg, B., Dawe, J. T., and Carmack, E. C.: Seasonal circulation over the Canadian Beaufort Shelf, in: On Thin Ice: a synthesis of the Canadian Arctic Shelf Exchange Study (CASES), Aboriginal Issues Press, Winnipeg, Manitoba, Canada, 14-35, 2008.

Jackson, J. M., Allen, S. E., Carmack, E. C., and McLaughlin, F. A.: Suspended particles in the Canada Basin from optical and bottle data, 2003-2008, Ocean Sci., 6, 799-813, https://doi.org/10.5194/os-6-799-2010, 2010.

Jackson, J. M., Melling, H., Lukovich, J. V., Fissel, D., and Barber, D. G.: Formation of winter water on the Canadian Beaufort shelf: New insight from observations during 2009-2011, J. Geophys. Res., 120, 4090-4107, https://doi.org/10.1002/2015JC010812, 2015.

Kirillov, S., Dmitrenko, I., Tremblay, B., Gratton, Y., Barber, D., and Rysgaard, S.: Upwelling of Atlantic water along the Canadian Beaufort Sea continental slope: Favorable atmospheric conditions and seasonal and interannual variations, J. Climate, 29, 4509-4523, doi.org/10.1175/JCLI-D-15-0804.1, 2016.

Kitchen, J. C., Zaneveld, J. R. V., and Pak, H.: Effect of particle size distribution and chlorophyll content on beam attenuation spectra, Appl. Opt., 21, 3913-3918, https://doi.org/10.1364/AO.21.003913, 1982.

Knap, A., Michaels, A., Close, A., Ducklow, H., and Dickson, A. (Eds.): Protocols for the Joint Global Ocean Flux Study (JGOFS) Core Measurements, JGOFS Report Nr. 19, vi+170 pp., Reprint of the IOC Manuals and Guides No. 29, UNESCO, 1996.

Lansard, B., Mucci, A., Miller, L. A., Macdonald, R. W., and Gratton, Y.: Seasonal variability of water mass distribution in the southeastern Beaufort Sea determined by total alkalinity and $\delta^{18} \mathrm{O}$, J. Geophys. Res., 117, C03003, https://doi.org/10.1029/2011JC007299, 2012.

Macdonald, R. W., Solomon, S. M., Cranston, R. E., Welch, H. E., Yunker, M. B., and Gobeil, C.: A sediment and organic carbon budget for the Canadian Beaufort shelf, Mar. Geol., 144, 255273, https://doi.org/10.1016/S0025-3227(97)00106-0, 1998.

Martin, J., Tremblay, J.-E., Gagnon, J., Tremblay, G., Lapoussière, A., Jose, C., Poulin, M., Gosselin, M., Gratton, Y. and Michel, C.: Prevalence, structure and properties of subsurface chlorophyll maxima in Canadian Arctic waters, Mar. Ecol.-Prog. Ser., 412, 69-84, https://doi.org/10.3354/meps08666, 2010.

Matsuoka, A., Bricaud, A., Benner, R., Para, J., Sempéré, R., Prieur, L., Bélanger, S., and Babin, M.: Tracing the transport of colored dissolved organic matter in water masses of the Southern Beaufort Sea: relationship with hydrographic characteristics, Biogeosciences, 9, 925-940, https://doi.org/10.5194/bg-9-9252012, 2012.

McClelland, J. W., Holmes, R. M., Dunton, K. H., and Macdonald, R. W.: The Arctic Ocean Estuary, Estuar. Coast., 35, 353-368, https://doi.org/10.1007/s12237-010-9357-3, 2012.

McPhee, M. G.: Intensification of Geostrophic Currents in the Canada Basin, Arctic Ocean, J. Climate, 26, 3130-3138, https://doi.org/10.1175/JCLI-D-12-00289.1, 2013.

Mol, J., Thomas, H., Myers, P. G., Hu, X., and Mucci, A.: Inorganic carbon fluxes on the Mackenzie Shelf of the Beaufort Sea, 
Biogeosciences, 15, 1011-1027, https://doi.org/10.5194/bg-151011-2018, 2018.

Moore, G. W. K.: Decadal variability and a recent amplification of the summer Beaufort Sea High, Geophys. Res. Lett., 39, L10807, https://doi.org/10.1029/2012GL051570, 2012.

Morel, A. and Bricaud, A.: Inherent optical properties of algal cells, including picoplankton: Theoretical and experimental results, Can. B. Fish. Aquat. Sci., 214, 521-559, 1986.

O'Brien, M. C., Macdonald, R. W., Melling, H., and Iseki, K.: Particle fluxes and geochemistry on the Canadian Beaufort Shelf: Implications for sediment transport and deposition, Cont. Shelf Res., 26, 41-81, https://doi.org/10.1016/j.csr.2005.09.007, 2006.

O'Brien, M. C., Melling, H., Pedersen, T. F., and Macdonald, R. W.: The role of eddies and energetic ocean phenomena in the transport of sediment from shelf to basin in the Arctic, J. Geophys. Res., 116, C08001, https://doi.org/10.1029/2010JC006890, 2011.

Pickart, R. S.: Shelfbreak circulation in the Alaskan Beaufort Sea: Mean structure and variability, J. Geophys. Res., 109, C04024, https://doi.org/10.1029/2003JC001912, 2004.

Reynolds, R. A., Stramski, D., Wright, V. M., and Woźniak, S. B.: Measurements and characterization of particle size distributions in coastal waters, J. Geophys. Res., 115, C08024, https://doi.org/10.1029/2009JC005930, 2010.

Reynolds, R. A., Stramski, D., and Neukermans, G.: Optical backscattering by particles in Arctic seawater and relationships to particle mass concentration, size distribution, and bulk composition, Limnol. Oceanogr., 61, 1869-1890, https://doi.org/10.1002/lno.10341, 2016.

Sallon, A., Michel, C., and Gosselin, M.: Summertime primary production and carbon export in the southeastern Beaufort Sea during the low ice year of 2008, Polar Biol., 34, 1989-2005, https://doi.org/10.1007/s00300-011-1055-5, 2011.

Stramska, M. and Stramski, D.: Variability of particulate organic carbon concentration in the north polar Atlantic based on ocean color observations with Sea-viewing Wide Fieldof-view Sensor (SeaWiFS), J. Geophys. Res., 110, C10018, https://doi.org/10.1029/2004JC002762, 2005.

Stramski, D. and Kiefer, D. A.: Light scattering by microorganisms in the open ocean, Prog. Oceanogr., 28, 343-383, doi.org/10.1016/0079-6611(91)90032-H, 1991.

Stramski, D., Reynolds, R. A., Babin, M., Kaczmarek, S., Lewis, M. R., Röttgers, R., Sciandra, A., Stramska, M., Twardowski, M. S., Franz, B. A., and Claustre, H.: Relationships between the surface concentration of particulate organic carbon and optical properties in the eastern South Pacific and eastern Atlantic Oceans, Biogeosciences, 5, 171-201, https://doi.org/10.5194/bg5-171-2008, 2008.
Stroeve, J. C., Markus, T., Boisvert, L., Miller, J., and Barrett, A.: Changes in Arctic melt season and implications for sea ice loss, Geophys. Res. Lett., 41, 1216-1225, https://doi.org/10.1002/2013GL058951, 2014.

Timmermans, M. L., Garrett, C., and Carmack, E.: The thermohaline structure and evolution of the deep waters in the Canada Basin, Arctic Ocean, Deep-Sea Res. Pt. I, 50, 1305-1321, 2003.

Tremblay, J.-É., Simpson, K., Martin, J., Miller, L., Gratton, Y., Barber, D., and Price, N. M.: Vertical stability and the annual dynamics of nutrients and chlorophyll fluorescence in the coastal, southeast Beaufort Sea, J. Geophys. Res., 113, C07S90, https://doi.org/10.1029/2007JC004547, 2008.

Tremblay, J.-É., Bélanger, S., Barber, D. G., Asplin, M., Martin, J., Darnis, G., Fortier, L., Gratton, Y., Link, H., Archambault, P., Sallon, A., Michel, C., Williams, W. J., Philippe, B., and Gosselin, M.: Climate forcing multiplies biological productivity in the coastal Arctic Ocean, Geophys. Res. Lett., 38, L18604, https://doi.org/10.1029/2011GL048825, 2011.

Williams, W. J. and Carmack, E. C.: Combined effect of wind-forcing and isobath divergence on upwelling at Cape Bathurst, Beaufort Sea, J. Mar. Res., 66, 645-663, https://doi.org/10.1357/002224008787536808, 2008.

Williams, W. J., Carmack, E. C., Shimada, K., Melling, H., Aagaard, K., Macdonald, R. W., and Ingram, R. G.: Joint effects of wind and ice motion in forcing upwelling in Mackenzie Trough, Beaufort Sea, Cont. Shelf Res., 26, 2352-2366, 2006.

Williams, W. J., Melling, H., Carmack, E. C., and Ingram, R. G.: Kugmallit Valley as a conduit for cross-shelf exchange on the Mackenzie Shelf in the Beaufort Sea, J. Geophys. Res., 113, C02007, https://doi.org/10.1029/2006JC003591, 2008.

Woźniak, S. B., Stramski, D., Stramska, M., Reynolds, R. A., Wright, V. M., Miksic, E. Y., Cichocka, M., and Cieplak, A. M.: Optical variability in relation to particle concentration, composition, and size distribution in the nearshore marine environment at Imperial Beach, California, J. Geophys. Res., 115, C08027, https://doi.org/10.1029/2009JC005554, 2010.

Yamamoto-Kawai, M., McLaughlin, F. A., Carmack, E. C., Nishino, S., and Shimada, K.: Freshwater budget of the Canada Basin, Arctic Ocean, from salinity, d180, and nutrients, J. Geophys. Res., 113, C01007, https://doi.org/10.1029/2006JC003858, 2008.

Yang, J.: Seasonal and interannual variability of downwelling in the Beaufort Sea, J. Geophys. Res., 114, C00A14, https://doi.org/10.1029/2008JC005084, 2009. 